\title{
A novel, long-acting glucagon-like peptide receptor-agonist: dulaglutide
}

This article was published in the following Dove Press journal:

Diabetes, Metabolic Syndrome and Obesity: Targets and Therapy

10 August 2015

Number of times this article has been viewed

\section{Tara Gurung' \\ Deepson S Shyangdan' \\ Joseph Paul O'Hare ${ }^{2}$ \\ Norman Waugh'}

'Warwick Evidence, ${ }^{2}$ Division of Metabolic and Vascular Health, Warwick Medical School, University of Warwick, Coventry, UK
Correspondence: Tara Gurung Warwick Evidence, Warwick Medical School, University of Warwick, Gibbet Hill Road, Coventry CV4 7AL, UK Tel +44247615 07II

Email t.gurung@warwick.ac.uk
Background: Dulaglutide is a new, long-acting glucagon-like peptide analogue in the treatment of type 2 diabetes. It is available in two doses, 0.75 and $1.5 \mathrm{mg}$, given by injection once weekly. This systematic review reports the effectiveness and safety of dulaglutide in type 2 diabetes in dual and triple therapy.

Methods: MEDLINE, MEDLINE In-Process and Other Non-Indexed Citations, EMBASE, and conference abstracts were searched from 2005 to August 2014, and updated in January 2015. Company websites and references of included studies were checked for potentially relevant studies. European Medicines Agency and US Food and Drug Administration websites were searched.

Results: Four trials were included. All were manufacturer-funded randomized controlled trials from the Assessment of Weekly Administration of Dulaglutide in Diabetes (AWARD) program. AWARD-1 compared dulaglutide $1.5 \mathrm{mg}$ against exenatide $10 \mu \mathrm{g}$ twice daily and placebo, AWARD-2 compared dulaglutide 0.75 and $1.5 \mathrm{mg}$ against insulin glargine, AWARD-5 compared dulaglutide 0.75 and $1.5 \mathrm{mg}$ against sitagliptin $100 \mathrm{mg}$ and placebo, and AWARD-6 compared dulaglutide $1.5 \mathrm{mg}$ against liraglutide $1.8 \mathrm{mg}$. The duration of follow-up in the trials ranged from 26 to 104 weeks. The primary outcome of all the included trials was change in $\mathrm{HbA}_{1 \mathrm{c}}$. At 26 weeks, greater $\mathrm{HbA}_{1 \mathrm{c}}$ reductions were seen with dulaglutide than with twice daily exenatide (dulaglutide $1.5 / 0.75 \mathrm{mg}:-1.5 \% /-1.3 \%$; exe: $0.99 \%$ ) and sitagliptin (1.5/0.75 mg $-1.22 \% /-1.01 \%$; sitagliptin: $-0.6 \%)$. $\mathrm{HbA}_{1 \mathrm{c}}$ change was greater with dulaglutide $1.5 \mathrm{mg}(-1.08 \%)$ than with glargine $(-0.63 \%)$, but not with dulaglutide $0.75 \mathrm{mg}(-0.76 \%)$. Dulaglutide $1.5 \mathrm{mg}$ was found to be noninferior to liraglutide $1.8 \mathrm{mg}$. More patients treated with dulaglutide achieved $\mathrm{HbA}_{1 \mathrm{c}}$ targets of $<7 \%$ and $\leq 6.5 \%$. Reduction in weight was greater with dulaglutide than with sitagliptin and exenatide. Hypoglycemia was infrequent. The main adverse events were nausea, diarrhea, and vomiting.

Conclusion: Dulaglutide is effective in the treatment of patients with type 2 diabetes but we need long follow-up data for safety concerns.

Keywords: dulaglutide, glucagon-like peptide analogue, type 2 diabetes, effectiveness, glycemic control

\section{Introduction}

\section{Type 2 diabetes mellitus}

Type 2 diabetes mellitus (formerly known as noninsulin dependent diabetes mellitus) is a chronic metabolic disease characterized by increased blood glucose levels (hyperglycemia), which over time can cause microvascular complications such as retinopathy, nephropathy, and neuropathy, and macrovascular complications such as ischemic heart disease and stroke. Patients with type 2 diabetes are usually overweight or obese, leading to insulin resistance. Initially, there is increased insulin production to counter 
this, but over time insulin production falls. The main aim of treatment of patients with type 2 diabetes is to achieve and maintain blood glucose levels and thereby reduce the occurrence of complications. ${ }^{1}$

Around 380 million people worldwide were known to have diabetes in 2013, and this figure is estimated to rise to 590 million by $2053 .^{2}$ The number of people suffering from type 2 diabetes will increase mainly due to rising prevalence of obesity, increasing life expectancy, and decreased physical activity. The cost of treating diabetes is also increasing worldwide. In 2013, around 550 billion USD was spent worldwide for diabetes. ${ }^{2}$

People with type 2 diabetes are initially managed by education on lifestyle changes, with advice to lose weight by changing dietary habits and increasing physical activity. If patients fail to improve their blood glucose level to the $\mathrm{HbA}_{1 \mathrm{c}}$ level of $<7 \%$, suggested as adequate glucose control by the American Diabetes Association (ADA) and the European Association for the Study of Diabetes (EASD), ${ }^{3,4}$ and maintain it, then they are usually started on metformin. A sulfonylurea (SU) is considered when patients cannot tolerate metformin or if it is contraindicated. However, other antidiabetic drugs such as dipeptidyl peptidase-4 (DPP-4) inhibitors, a thiazolidinediones, or sodium glucose transport 2 (SGLT2) inhibitors may be considered according to individual patients' need. ${ }^{4}$ If patients fail to achieve satisfactory control on metformin, another oral glucose-lowering drug is added, usually SU added to metformin (a combination of two oral agents is referred to as "dual therapy"). When dual therapy fails, a third drug is added (the combination is referred to as "triple therapy"). The third drug could be an oral glucose-lowering drug of another class such as pioglitazone, DPP-4 inhibitors (such as sitagliptin or saxagliptin), or a SGLT2 inhibitor (such as dapagliflozin or canagliflozin), or an injectable glucagon-like peptide-1 (GLP-1) analogue (liraglutide or exenatide, albiglutide, and now dulaglutide). Some GLP-1 receptor agonists are now available in long-acting form given only once a week. In type 2 diabetes, postprandial hyperglycemia is common. The rise in blood glucose level may be partly because of high glucagon levels. The incretin-based drugs reduce the increased postprandial glucagon level. There are two types of incretin-based drugs, DPP-4 inhibitors and GLP-1 receptor agonists.

\section{The glucagon-like peptide-I receptor agonists}

GLP-1 receptor agonists are glucose-lowering drugs that have to be injected. The GLP-1 receptor agonists act like the naturally occurring incretin hormone GLP-1, a gastrointestinal hormone that is secreted by the body following consumption of food, that regulates plasma glucose levels by delaying gastric emptying of food and reducing hunger, by inhibiting secretion of glucagon, and by stimulating secretion and biosynthesis of insulin. ${ }^{5,6}$ GLP-1 receptor agonists thus leads to glucose control and reduces weight.

There are more details about mechanism of action of GLP-1 receptor agonists, and the differences between long-acting and short-acting forms, in several good quality systematic reviews. ${ }^{7-11}$

There are now five GLP-1 receptor agonists available in the market: exenatide in twice daily form (Byetta, AstraZeneca plc, London, UK) and as the long-acting, once-weekly version (Bydureon, AstraZeneca), once-daily liraglutide (Victoza, Novo Nordisk A/S, Bagsværd, Denmark), once-daily lixisenatide (Lyxumia, Sanofi-Aventis, Bridgewater, NJ, USA), weekly albiglutide (Tanzeum, GlaxoSmithKline plc, London, UK), and recently, weekly dulaglutide (Eli Lilly and Company, Indianapolis, IN, USA). Taspoglutide (GlaxoSmithKline) has been dropped from the market following serious risk of hypersensitivity reactions and gastrointestinal side effects. In the UK, GLP-1 receptor agonists are recommended as triple therapy, ${ }^{12}$ while in USA, they are often used in dual therapy. ${ }^{3}$

\section{Dulaglutide}

Dulaglutide (trade name Trulicity) is manufactured by Eli Lilly. It is a once-weekly injectable GLP-1 analogue, ${ }^{13}$ and is "indicated as an adjunct to diet and exercise to improve glycemic control in adults with type 2 diabetes ... is not recommended as first-line therapy for patients inadequately controlled on diet and exercise". ${ }^{13,14}$ Dulaglutide has already been approved by the US Food and Drug Administration $(\text { FDA })^{15}$ and European Medicines Agency (EMA) ${ }^{14}$ as indicated above. Similar to all GLP-1 receptor agonists, there are also alerts about risk of thyroid C-cell tumors, pancreatitis, and hypersensitivity reactions. ${ }^{13,14}$

This systematic review assesses the effectiveness of dulaglutide in type 2 diabetes mellitus in dual and triple therapy (AWARD [Assessment of Weekly Administration of Dulaglutide in Diabetes] 1, 2, 5 and 6).

\section{Methods}

\section{Search strategies}

An iterative procedure was followed to develop a search strategy with input from previous systematic reviews. ${ }^{16}$ Comprehensive electronic searches identified references relating to type 2 diabetes and dulaglutide. Searches were undertaken in August 2014 in MEDLINE, MEDLINE 
In-Process and Other Non-Indexed Citations, EMBASE (via OVID), Science Citation Index, and Conference Proceedings (via Web of Knowledge). The databases were searched from 2005 to August 2014; the actual date range for each of the databases searched depended on the coverage of the individual database. In addition, company websites and references of included studies were also checked for potentially relevant studies. The searches were updated in January 2015, but we did not find any new studies to include in the review.

The websites of the FDA and the European Medicines Evaluation Agency (EMEA) were searched for information on the efficacy and safety. Current controlled trials http:// www.controlled-trials.com and clinicaltrials.gov were also checked for ongoing trials.

All the retrieved records were collected in a specialized database Endnote X7. Duplicate records were identified and removed from the database.

Details of the electronic search strategies used for the review of the clinical effectiveness are given in Table S1.

\section{Study selection}

Two independent reviewers (TG and DS) screened all the identified titles and abstracts. Potentially relevant full texts reports were then retrieved and examined separately. Disagreements between the two reviewers were resolved by a third reviewer $(\mathrm{NW})$.

The study flow and reasons for exclusion of full text papers were documented in the preferred reporting items for systematic reviews and meta-analyses (PRISMA) study flow diagram (Figure 1).

Our inclusion criteria were randomized controlled trials (RCTs) that included adults (over 18 years of age) with type 2 diabetes inadequately controlled with oral glucose-lowering drugs. We mainly included articles published in full, but meeting abstracts were considered if they, or published protocols, contained sufficient data on outcomes, study design, and quality. Trials with minimum duration of 12 weeks with dulaglutide in combination with metformin or SU or both were considered.

Since GLP-1 agonists are not licensed for use as first-line therapy in treatment of naïve patients, the inclusion criteria are based on the comparisons which are considered to be relevant to clinical practice as suggested by the National Institute for Health and Care Excellence (NICE) guideline (NICE CG66), SIGN guideline, and by the ADA/EASD joint statement..$^{3,17,18}$ The draft NICE

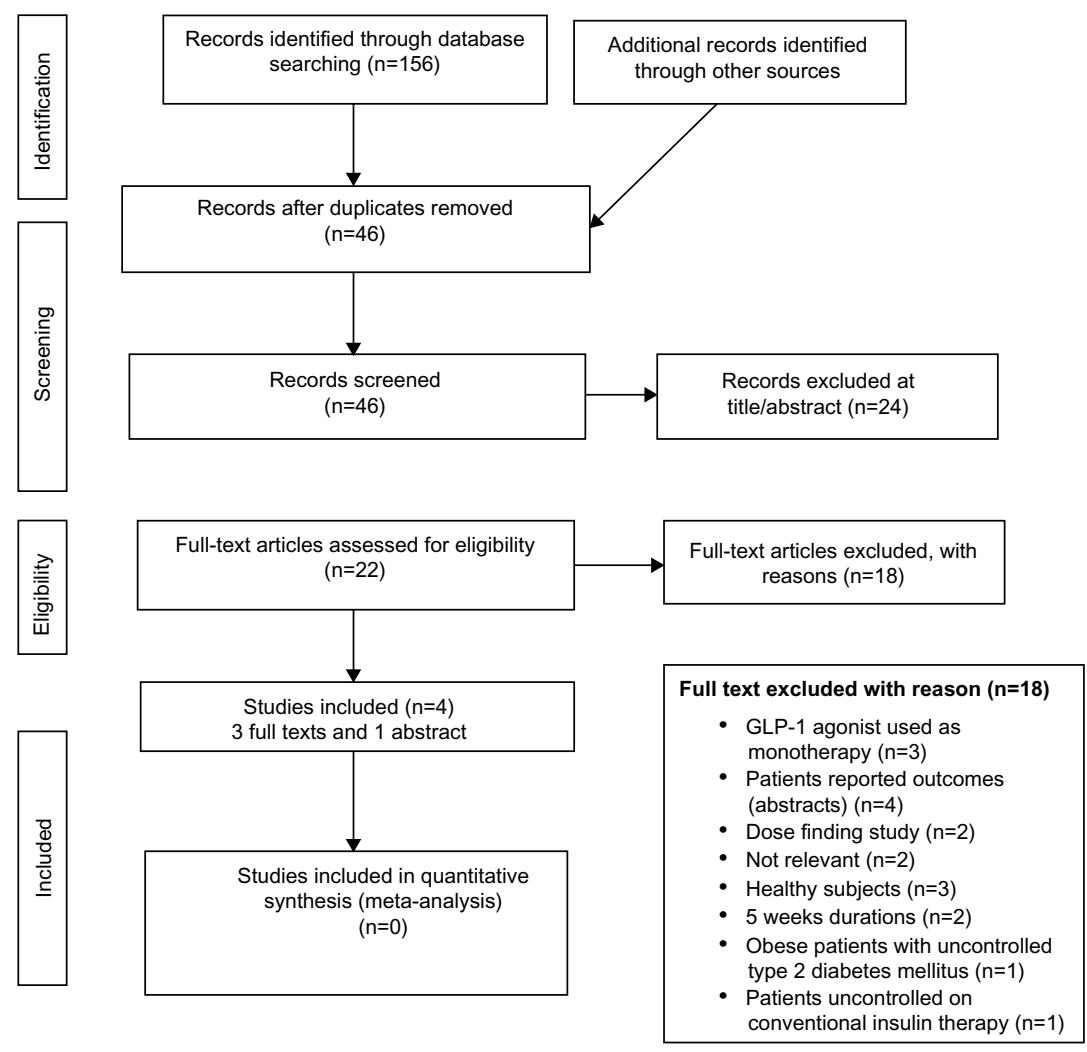

Figure I PRISMA flow diagram.

Abbreviations: PRISMA, preferred reporting items for systematic reviews and meta-analyses; GLP-I, glucagon-like peptide-I . 
2015 guideline for type 2 diabetes adopts a similar position. ${ }^{19}$

Our exclusion criteria were:

- Use of dulaglutide in patients naïve to treatment, ie, patients need to have been diagnosed with type 2 diabetes for at least a year and on at least one oral hypoglycemic drug for 6 months. If trials did not give sufficient detail, we accepted them if the mean duration of diabetes exceeded 2 years.

- Dulaglutide used as a monotherapy, whether compared with placebo or another drug.

- Trials of dulaglutide on patients who have failed only on an SU or a glitazone without having been tried on metformin. In practice, some trials include people who have failed on either a metformin or an SU, and may not give results separately. We accepted such trials if 70\% or more had been on metformin.

- Trials or arms using nonstandard doses were excluded.

The dosages of dulaglutide in the trials were 0.75 and $1.5 \mathrm{mg}$ (both doses are marketed).

\section{Validity assessment}

The RCTs were quality-assessed by two authors (TG and DS) using the Cochrane collaboration risk of bias (ROB) tool. The criteria include method of randomization; allocation concealment; blinding of participants; incomplete outcome data or missing data by investigating dropout, losses to follow-up, and withdrawals; reporting bias and whether groups were comparable at baseline; and sample size calculation. Any disagreements were resolved by consensus.

The risk of bias assessment falls into three categories of high, low, and unclear risk of bias. The assessments were provided in ROB tables and summary graphs.

\section{Data abstraction}

Relevant data were extracted independently by two reviewers using predefined prepiloted extraction forms. The extracted data included details of study (eg, author, country, design, study duration, study intervention, and outcome measures). The extracted data were checked by the second reviewer and any disagreements were resolved via discussion. If necessary, further discrepancies were resolved by a third reviewer.

Primary outcomes measures were:

- glycemic control as measured by glycated hemoglobin $\left(\mathrm{HbA}_{1 \mathrm{c}}\right)$

- hypoglycemia, graded as mild (symptoms easily controlled by individual), moderate (normal activities interrupted but assistance not required), severe (individual requiring assistance, and associated with blood glucose level less than $50 \mathrm{mg} / \mathrm{dL}$ [3.4 mmol/L] or with prompt recovery after oral carbohydrate or glucagon or intravenous glucose) (DCCT 1993), serious (life threatening or required subject to be admitted to hospital). However, definition of hypoglycemia may slightly vary in AWARD trials and any variation in this has been taken into consideration. Note that in the trials, a cutoff of 3.9 was used, which is above the lower limit of normal, and hence exaggerates the frequency of hypoglycemia.

- weight gain or loss/change in body mass index Other outcomes were:

- FPG (fasting blood glucose)

- PPG (postprandial glucose)

- plasma lipids

- $\beta$-cell function (HOMA [homeostatic model assessment] cell function)

- heart rate

- blood pressure

- health-related quality of life.

\section{Data synthesis}

Dichotomous data were expressed as relative risk. Continuous data were expressed as weighted mean differences with 95\% confidence intervals (CIs). Analysis was done comparing dulaglutide against placebo and active comparators.

\section{Results}

One hundred and fifty-six articles were retrieved through electronic searches, of which, 46 records were screened after removing duplicates. Of these, 24 records were excluded at title/abstract. The remaining 22 records were examined in full. Of these 22 records, only four papers were included, all RCTs based on the AWARD program (AWARD 1, 2, 5, and 6). ${ }^{20-23}$ AWARD-2 was available in abstract form; however, this was included since adequate information were reported. The main reason for exclusion were use of dulaglutide as monotherapy (AWARD-3), ${ }^{18}$ type 2 diabetes patients uncontrolled on conventional insulin therapy (AWARD-4), ${ }^{24}$ and studies published only as abstracts (with insufficient details).

\section{Study characteristics}

The characteristics of the four included RCTs are summarized in Table 1. Two trials (AWARD 1 and 6) ) $^{20,23}$ were conducted in multiple sites in many countries. Dungan et $\mathrm{al}^{20}$ conducted AWARD-6 at 62 sites in 9 countries: Czech Republic, Germany, Hungary, Mexico, Poland, Romania, Spain, Slovakia, and USA. Wysham et $\mathrm{al}^{23}$ conducted AWARD-1 in three countries namely Mexico, Argentina, and USA. 


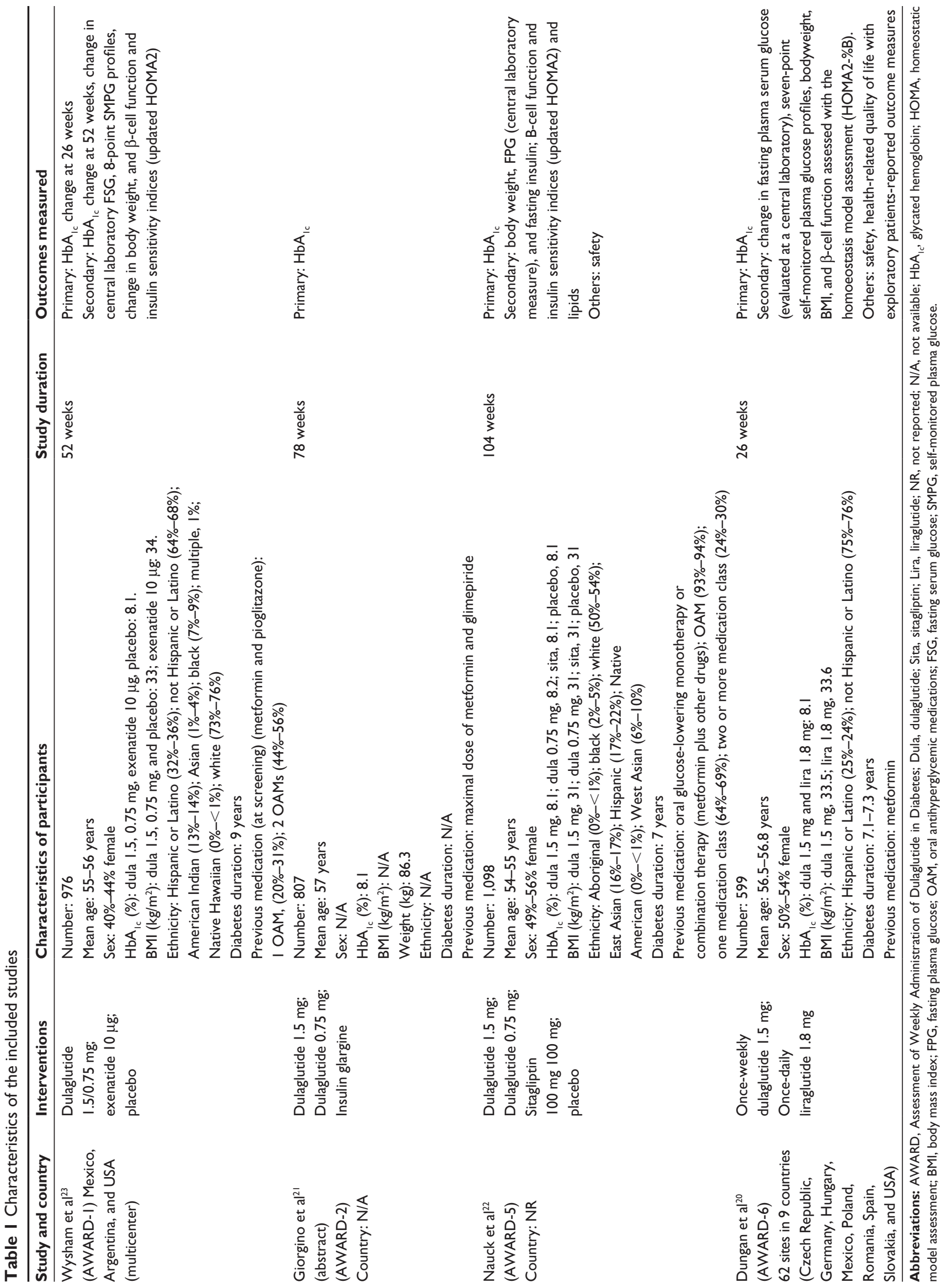


The remaining studies (AWARD 2 and 5) did not report details of study sites. A total of 3,480 participants were randomized across the four RCTs with the individual trial sample sizes ranging from $599^{20}$ to $1,098^{22}$ participants.

The mean age of participants in the trials ranged from $53^{22}$ to $57^{21}$ years. Mean baseline $\mathrm{HbA}_{1 \mathrm{c}}$ was $8.1 \%$, and mean body mass index (BMI) ranged between $31^{22}$ and $34^{23} \mathrm{~kg} / \mathrm{m}^{2}$. The proportion of females in the studies was $40 \%{ }^{23}-56 \%{ }^{22}$. The duration of the trials ranged from $26^{20}$ to 104 weeks. ${ }^{22}$ The two doses, 1.5 and $0.75 \mathrm{mg}$, of dulaglutide were compared against exenatide $10 \mu \mathrm{g}$ twice daily, ${ }^{23}$ sitagliptin $100 \mathrm{mg},{ }^{22}$ and glargine. ${ }^{21}$ One trial compared dulaglutide $1.5 \mathrm{mg}$ with liraglutide $1.8 \mathrm{mg} .{ }^{20}$ All the four trials were sponsored by Eli Lilly and Company.

There were no trials against lixisenatide or against weekly exenatide.

\section{AWARD-I (dulaglutide vs exenatide $10 \mu g$ )}

A randomized controlled, multicenter, parallel-arm study was conducted in 976 people with type 2 diabetes, aged between 55 and 56 years. ${ }^{23}$ The participants were randomized to dulaglutide $1.5 \mathrm{mg}$, dulaglutide $0.75 \mathrm{mg}$, exenatide $10 \mu \mathrm{g}$, and placebo. The duration of the study was 52 weeks. The primary outcome measure was mean change in $\mathrm{HbA}_{1 \mathrm{c}}$ from baseline to 26 weeks. The secondary efficacy measures were mean change in $\mathrm{HbA}_{1 \mathrm{c}}$ from baseline to 52 weeks.

\section{AWARD-2 (dulaglutide vs glargine)}

A randomized controlled, parallel-arm, open-label 78 weeks study was conducted in 807 people with type 2 diabetes. ${ }^{21}$ The mean age of participants was 57 years. The study compared once-weekly dulaglutide $1.5 \mathrm{mg}$ or dulaglutide $0.75 \mathrm{mg}$ against insulin glargine in combination with metformin and glimepiride. The dose of glargine could be titrated to try to achieve target level. At baseline, mean $\mathrm{HbA}_{1 \mathrm{c}}$ and mean weight were $8.1 \%$ and $86.5 \mathrm{~kg}$, respectively. The outcome measures were change in $\mathrm{HbA}_{1 \mathrm{c}}$ (percentages of patients with $\mathrm{HbA}_{1 \mathrm{c}}<7.0 \%$ ) and weight change from baseline to 52 and 78 weeks.

\section{AWARD-5 (dulaglutide vs sitagliptin $100 \mathrm{mg}$ )}

A randomized controlled, multicenter, double blind study comparing the two doses of dulaglutide ( 1.5 and $0.75 \mathrm{mg}$ ) vs sitagliptin $100 \mathrm{mg}$ or placebo add on to metformin in 1,098 patients with type 2 diabetes. ${ }^{22}$ The mean baseline age of participants ranged between 54 and 55 years. At baseline, mean $\mathrm{HbA}_{1 \mathrm{c}}$ was $8.1 \%$ and weight $86.4 \mathrm{~kg}$. The study lasted for 104 weeks. The primary outcome measure was change in $\mathrm{HbA}_{1 \mathrm{c}}$ from baseline to 52 weeks.
AWARD-6 (dulaglutide $1.5 \mathrm{mg}$ vs liraglutide $1.8 \mathrm{mg}$ )

This was a randomized, multicenter, open-label, parallelgroup study conducted in 62 sites, in nine countries, in patients with type 2 diabetes inadequately controlled with metformin ${ }^{20}$ The study compared once-weekly dulaglutide $1.5 \mathrm{mg}$ against liraglutide $1.8 \mathrm{mg}$ once daily. The duration of the study was 26 weeks. Mean baseline age of participants was 57 years, $\mathrm{HbA}_{1 \mathrm{c}}$ was $8.1 \%$, and weight ranged between 94 and $95 \mathrm{~kg}$. The primary outcome measure was change in $\mathrm{HbA}_{1 \mathrm{c}}$ from baseline to 26 weeks.

\section{Study quality}

Three studies (AWARD 1, 5, and 6) ${ }^{20,22,23}$ were rated as having low risk of bias and one (AWARD-2) $)^{21}$ was rated as having unclear risk (Figure 2). Random sequence generation and allocation concealment were adequate (low risk) in two trials (AWARD 1 and 6 ), ${ }^{20,23}$ but were unclear in the other two trials (AWARD 2 and 5). ${ }^{21,22}$ Two trials (AWARD 2 and 6) (20,21 $^{2}$ were open label, but in one trial ${ }^{20}$ "the participants, treating physicians, investigators, and sites staff were not blinded to the treatment allocation, however the study statistician and medical personnel from the sponsors were blinded". The AWARD-5 trial ${ }^{22}$ was a double blinded study, whereas the design of AWARD-2 was unclear. ${ }^{21}$ Other domains such as attrition bias and reporting bias were satisfactory in three trials (AWARD 1, 5, and 6), ${ }^{20,22,23}$ but unclear in AWARD-2. ${ }^{21}$ The baseline characteristics were comparable in AWARD 1 , 5 , and $6 .{ }^{20,22,23}$ The sample size calculation was unclear in AWARD 1 and 2.21,23

\section{Change in $\mathrm{HbA}_{\mathrm{Ic}}$ from baseline AWARD-I}

Figure 3 (created using the data reported) shows that at 26 weeks, dulaglutide led to greater reduction in $\mathrm{HbA}_{1 \mathrm{c}}$ than exenatide $10 \mu \mathrm{g}$ twice daily or placebo. ${ }^{23}$ The least square (LS) mean changes from baseline to 26 weeks were $-1.5 \%$; standard deviation (SD), 1.002 and $-1.30 \%$; SD, 1.003, respectively, with dulaglutide 1.5 and $0.75 \mathrm{mg}$ and $-0.99 \%$; $\mathrm{SD}, 0.99$ with exenatide $10 \mu \mathrm{g}$ and $-0.46 \%$ with placebo.

Similarly, the LS mean $\mathrm{HbA}_{1 \mathrm{c}}$ changes from baseline to 52 weeks were $-1.36 \%$; SD, 1.33 with dulaglutide $1.5 \mathrm{mg},-1.07 \%$; SD, 1.33 with $0.75 \mathrm{mg}$, and $-0.80 \%$ with exenatide $10 \mu \mathrm{g}$.

\section{AWARD-2}

Figure 3 shows the $\mathrm{HbA}_{1 \mathrm{c}}$ changes from baseline at 52 and 78 weeks. ${ }^{21}$ At both time-points, the reductions with dulaglutide $1.5 \mathrm{mg}(-1.08 \%$; SD, 0.9 and $-0.9 \%$; SD, 1.1 at 


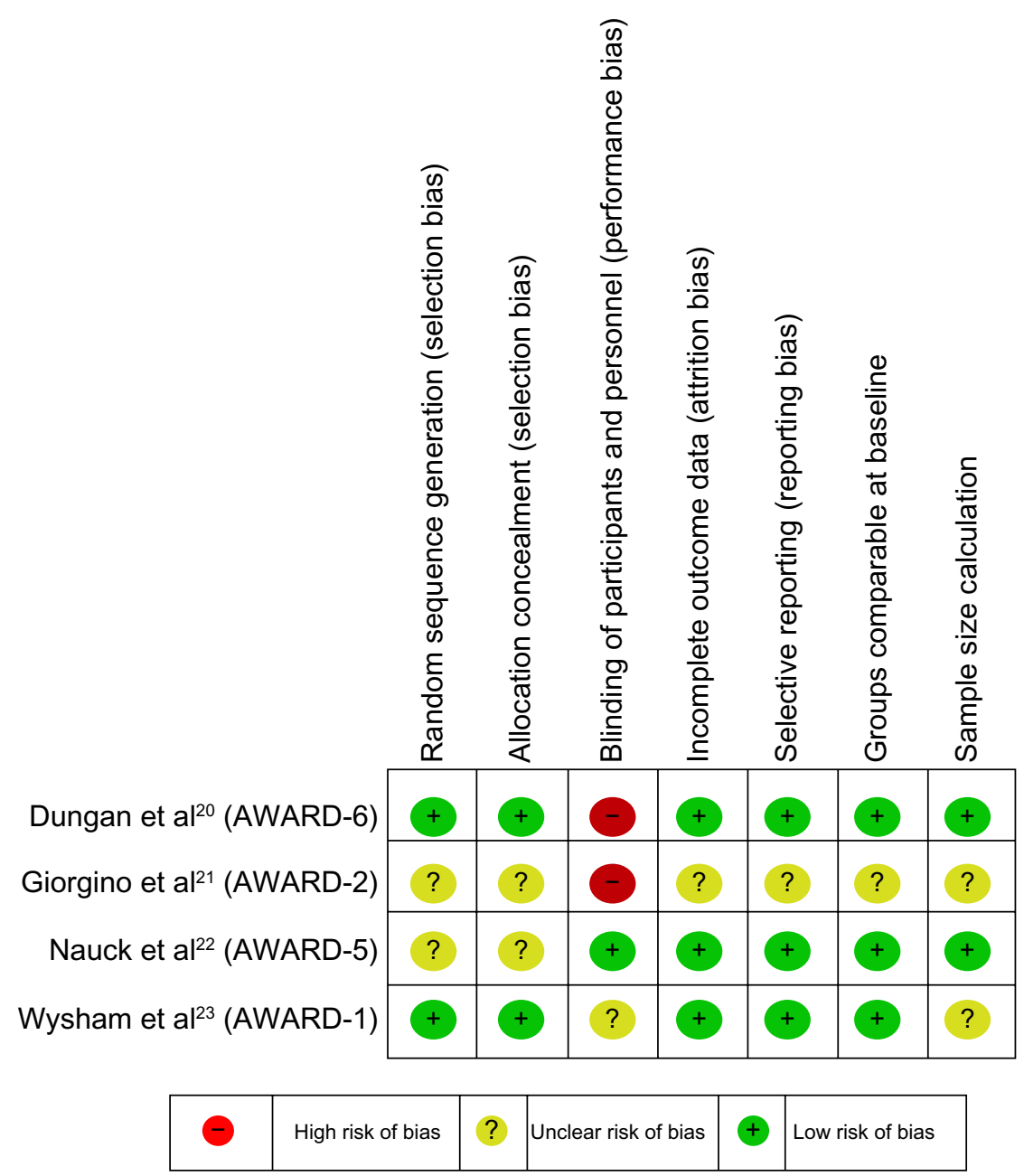

Figure 2 Risk of bias.

Abbreviation: AWARD, Assessment of Weekly Administration of Dulaglutide in Diabetes.

52 and 78 weeks, respectively) were greater $(P<0.001)$ than with insulin glargine $(-0.63 \%$; SD, 0.9 and $-0.59 \%$; SD, 1.1 , respectively). The reductions with dulaglutide $0.75 \mathrm{mg}$ $(-0.76 \%$; SD, 0.9 and $-0.62 \%$; SD, 1.1 , respectively) were noninferior to insulin glargine. The mean dose of glargine at study end was not reported.

\section{AWARD-5}

At 26 weeks, the mean changes in $\mathrm{HbA}_{1 \mathrm{c}}$ from baseline to 26 weeks were statistically significantly greater with both doses of dulaglutide $(P<0.001)$ than with placebo and sitagliptin $100 \mathrm{mg}$ (Figure 4). ${ }^{22}$ At 52 weeks, the mean $\mathrm{HbA}_{1 \mathrm{c}}$ changes from baseline were significantly greater $(P<0.001)$ with both doses of dulaglutide $(-1.1 \%$; SD, 1.04 with dulaglutide $1.5 \mathrm{mg},-0.87 \%$; SD, 1.04 with dulaglutide $0.75 \mathrm{mg}$ ) compared to sitagliptin $100 \mathrm{mg}(-0.39 \%$; SD, 1.06). At 104 weeks, both doses of dulaglutide were reported to be statistically superior to sitagliptin $100 \mathrm{mg}$ (Figure 4).

\section{AWARD-6}

AWARD-6 reported that dulaglutide $1.5 \mathrm{mg}$ was noninferior to liraglutide $1.8 \mathrm{mg} .{ }^{20}$ Both drugs significantly reduced $\mathrm{HbA}_{1 \mathrm{c}}$ from baseline (Figure 4). The mean treatment difference was $-0.06 \%$ ( $95 \% \mathrm{CI},-0.19$ to 0.07 ; noninferiority $<0.0001)$.

\section{Proportion of patients achieving $\mathrm{HbA}_{\mathrm{Ic}}$ target of $<7 \%$ and $\leq 6.5 \%$ AWARD-I}

At 26 weeks, the percentages of patients who achieved the target of $<7 \%$ were significantly higher in both dulaglutide arms (1.5 $\mathrm{mg}[78 \%]$ and $0.75 \mathrm{mg}[66 \%])$ than in the exenatide $(52 \%)(P<0.001$, both comparisons $)$ and placebo arm $(43 \%)$ $\left(P<0.001\right.$, both comparisons) (Figure 5). ${ }^{23}$ Similarly, $\mathrm{HbA}_{1 \mathrm{c}}$ target of $\leq 6.5 \%$ was achieved by significantly greater proportions of patients in the two dulaglutide treatment arms $(63 \%,-1.5 \mathrm{mg} ; 53 \%,-0.75 \mathrm{mg})$ compared to the exenatide 
A

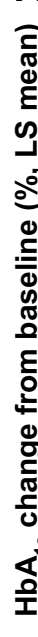

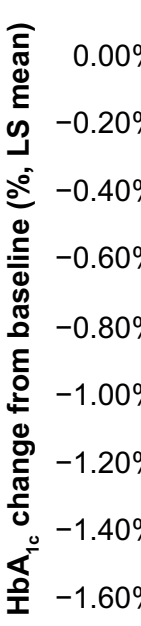

AWARD-1
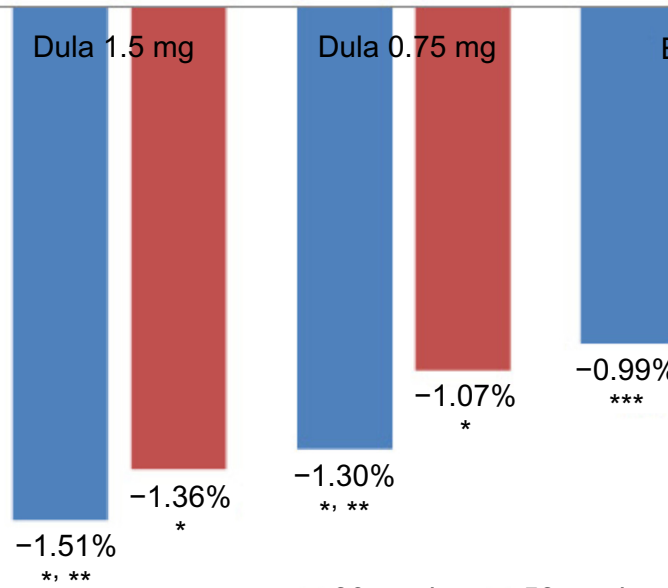

26 weeks

52 weeks

B

AWARD-2
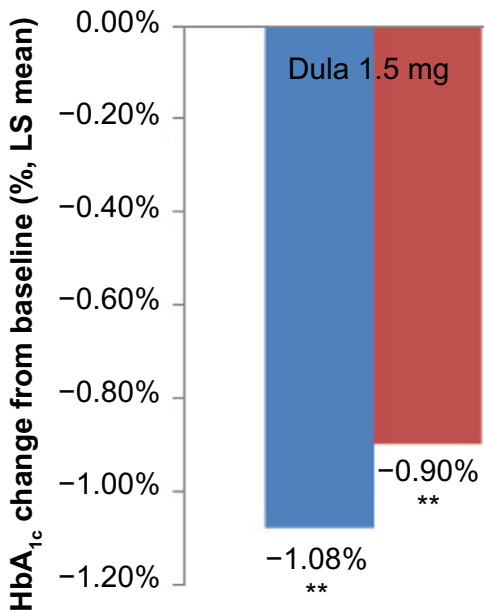

\section{Dula $0.75 \mathrm{mg}$}
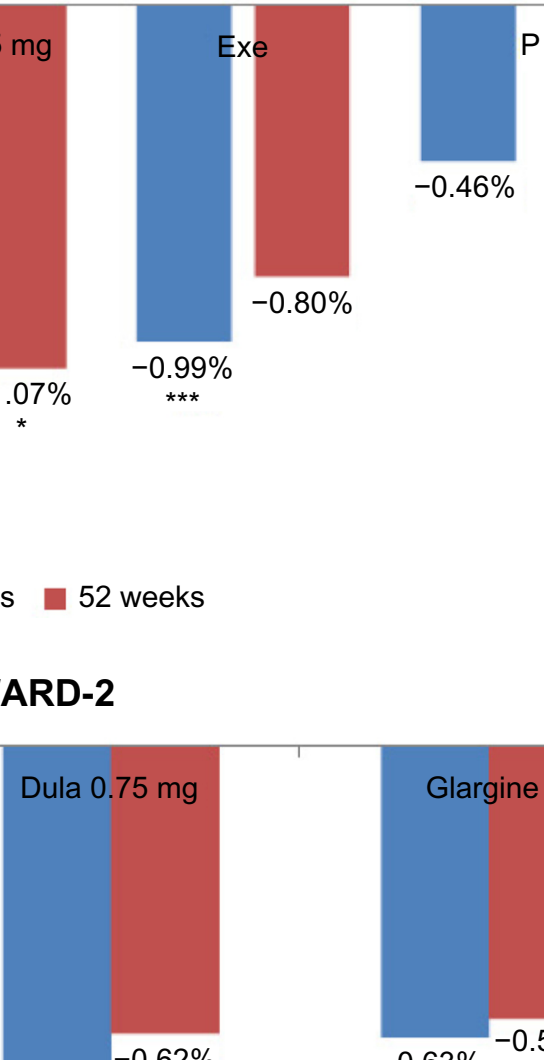

$-0.46 \%$

$-0.80 \%$

$-0.76 \%$

Figure 3 Mean change in $\mathrm{HbA}$ from baseline to follow-up (AWARD I and 2).

Notes: (A) AWARD-I: $* P<0.00$ I, superiority vs exenatide; $* * P<0.001$, superiority vs placebo; $* * * P<0.001$ vs placebo. (B) AWARD-2: $* * *$ indicate multiplicity adjusted one-sided $P<0.00$ I for noninferiority or superiority vs glargine, respectively.

Abbreviations: LS, least square; $\mathrm{HbA}_{\mathrm{lc}}$, glycated hemoglobin; AWARD, Assessment of Weekly Administration of Dulaglutide in Diabetes; Dula, dulaglutide; Exe, exenatide; P, placebo.

(38\%) and placebo (24\%) arms ( $P<0.0001$, all comparisons). At 52 weeks, $57 \%$ of patients in the dulaglutide $1.5 \mathrm{mg}$ arm and $48 \%$ of patients in the $0.75 \mathrm{mg}$ dulaglutide arm achieved $\mathrm{HbA}_{1 \mathrm{c}}$ target of $\leq 6.5 \%$ compared to only $35 \%$ in the exenatide arm.

An additional post hoc analysis from the same trial ${ }^{22}$ was conducted to determine the influence of baseline $\mathrm{HbA}_{1 \mathrm{c}}$ $(<8.5 \%$ and $\geq 8.5 \%)$ at 26 weeks. For those with baseline $\mathrm{HbA}_{1 \mathrm{c}}$ of $<8.5 \%$, the LS mean changes from baseline in $\mathrm{HbA}_{1 \mathrm{c}}$ were greater with dulaglutide $1.5 \mathrm{mg}(P<0.001)$ than with placebo and exenatide. The proportions of patients reaching targets of $<7 \%$ and $\leq 6.5 \%$ were also significantly more $(P<0.05)$ on dulaglutide $1.5 \mathrm{mg}$ compared to placebo and exenatide (Table 2). Dulaglutide $0.75 \mathrm{mg}$ led to significant changes for both baseline groups compared to placebo $(P<0.05)$. However, in those with baseline $\mathrm{HbA}_{1 \mathrm{c}}$ of $\geq 8.5 \%$, the change in $\mathrm{HbA}_{1 \mathrm{c}}$ with dulaglutide $0.75 \mathrm{mg}$ was not statistically significantly different compared to exenatide $10 \mu \mathrm{g}$.

\section{AWARD-2}

The trial only reported the results of those achieving an $\mathrm{HbA}_{1 \mathrm{c}}$ target of $<7 \%$ at 52 and 78 weeks. ${ }^{21}$ At 52 weeks, around $53 \%$ and $37 \%$ of patients met the target of $<7 \%$ with dulaglutide 1.5 and $0.75 \mathrm{mg}$, respectively, compared to $31 \%$ 
A

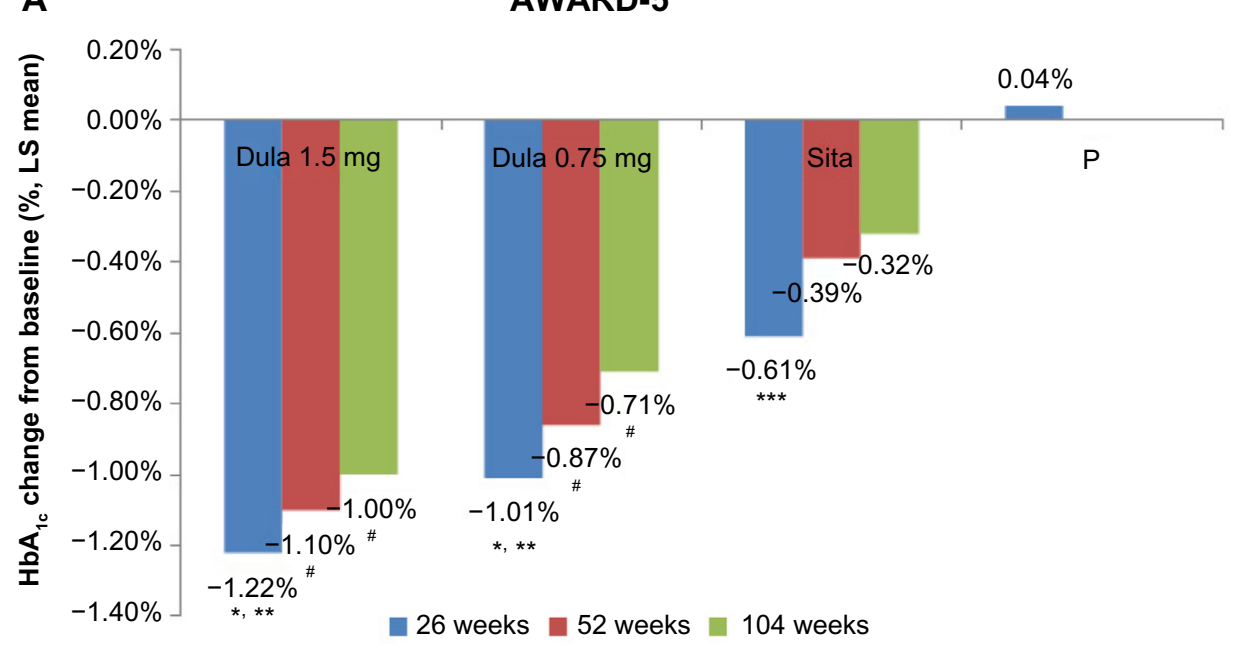

B

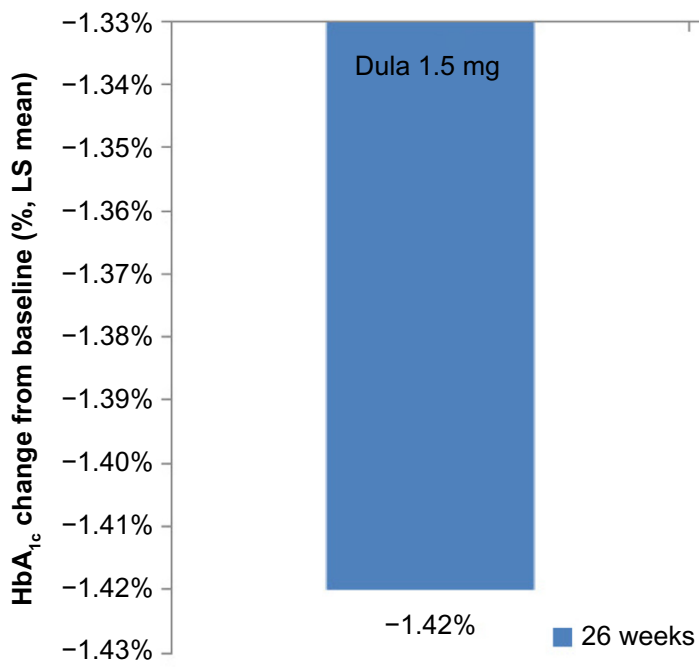

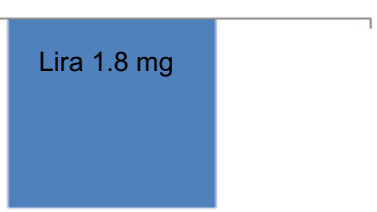

$-1.36 \%$

Figure 4 Mean change in $\mathrm{HbA}_{\mathrm{lc}}$ from baseline to follow-up (AWARD 5 and 6).

Notes: (A) AWARD-5: $* P<0.00$ I vs sitagliptin; $* * P<0.00$ I, superiority vs placebo; $* * * P<0.00$ I vs placebo; ${ }^{*} P<0.00$ I, superiority vs sitagliptin. (B) AWARD-6: $P<0.000$ I noninferiority of dulaglutide vs liraglutide.

Abbreviations: LS, least square; $\mathrm{HbA}_{1 \mathrm{c}}$, glycated hemoglobin; AWARD, Assessment of Weekly Administration of Dulaglutide in Diabetes; Dula, dulaglutide; P, placebo; Sita, sitagliptin; Lira, liraglutide.

with insulin glargine $(P<0.05)$ (Figure 5). At 78 weeks, $49 \%$ of patients with dulaglutide $1.5 \mathrm{mg}$ and $34 \%$ patients with dulaglutide $0.75 \mathrm{mg}$ achieved the $\mathrm{HbA}_{1 \mathrm{c}}$ target compared to $30 \%$ of patients with glargine $(P<0.05)$.

\section{AWARD-5}

Overall, the proportions of patients achieving an $\mathrm{HbA}_{1 \mathrm{c}}$ target of $<7 \%$ and $\leq 6.5 \%$ at weeks 26,52 , and 104 were significantly greater with dulaglutide 1.5 and $0.75 \mathrm{mg}$ compared to sitagliptin $100 \mathrm{mg}$ and placebo (Figure 6). ${ }^{22}$ At 26 weeks, the percentages of patients attaining $<7 \%$ target were $61 \%$ and $55 \%$ in the dulaglutide 1.5 and $0.75 \mathrm{mg}$ treatment groups, respectively, compared to $38 \%$ in the sitagliptin $100 \mathrm{mg}$ group
$(P<0.001$, all comparisons) and $21 \%$ in the placebo group ( $P<0.001$, both comparisons). At 26 weeks, $47 \%$ in the dulaglutide $1.5 \mathrm{mg}$ and $31 \%$ in the dulaglutide $0.75 \mathrm{mg}$ groups compared with $22 \%$ in the sitagliptin $100 \mathrm{mg}(P<0.001$, both comparisons) and $13 \%$ in the placebo arm $(P<0.001$, both comparisons; $P=0.005$, sitagliptin $100 \mathrm{mg}$ comparison with placebo) achieved the target of $\leq 6.5 \%$

At 52 and 104 weeks, the proportions of patients achieving the target level of $<7 \%$ were greater in the two dulaglutide groups (58\% with $1.5 \mathrm{mg}$ dulaglutide; $49 \%$ with $0.75 \mathrm{mg}$ dulaglutide) than in the sitagliptin $100 \mathrm{mg}$ group (33\%). More patients in the two dulaglutide groups ( $42 \%$ with $1.5 \mathrm{mg}$ dulaglutide; $29 \%$ with $0.75 \mathrm{mg}$ dulaglutide) 
A

AWARD-1

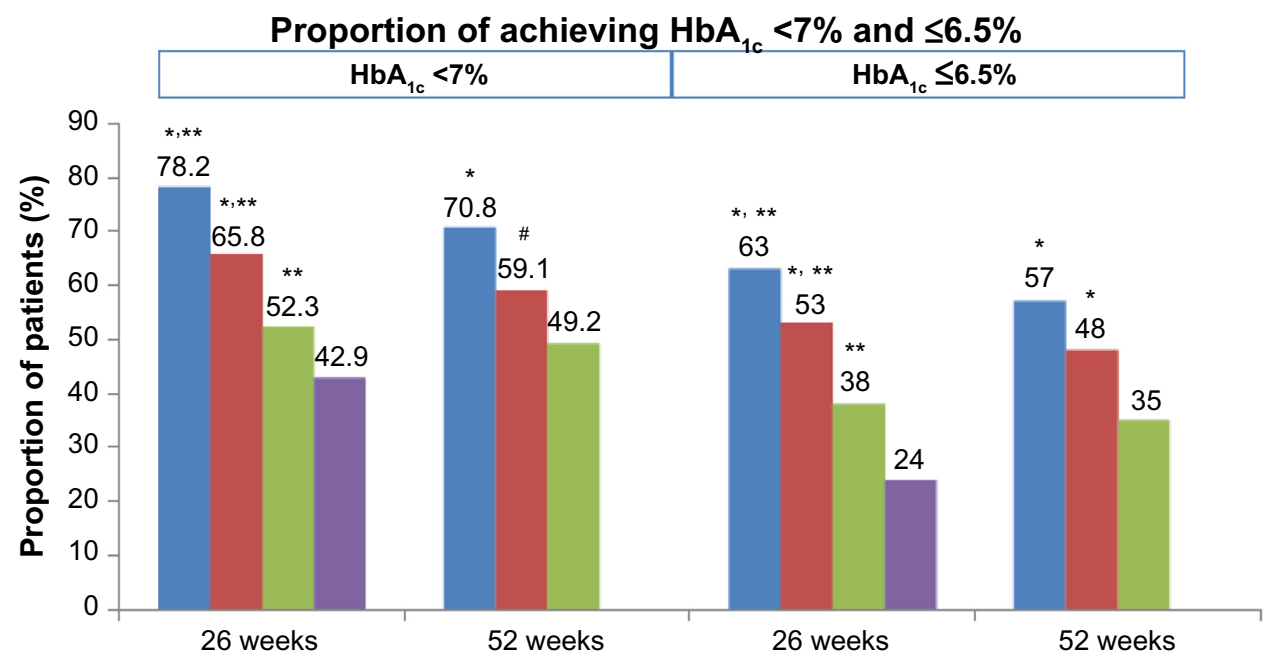

Dula $1.5 \mathrm{mg} \square$ Dula $0.75 \mathrm{mg} \square$ Exe $\square \mathrm{P}$

AWARD-2

B Proportion of achieving $\mathrm{HbA}_{1 \mathrm{c}}<7 \%$

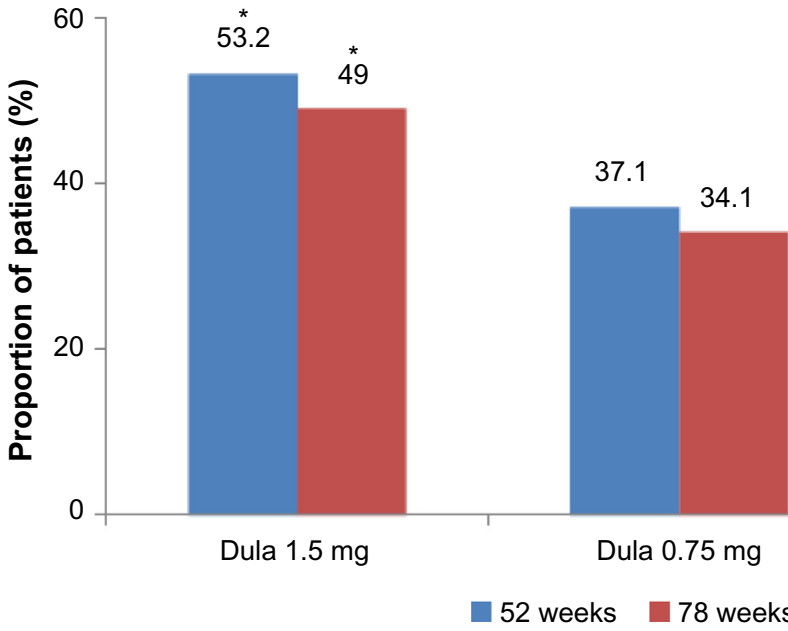

Figure 5 Proportion of patients achieving a target $\mathrm{HbA}_{\mathrm{lc}}$ level of $<7 \%$ and $\leq 6.5 \%$ (AWARD I and 2).

Notes: (A) AWARD-I: ${ }^{*} P<0.00$ I vs exenatide; ${ }^{*} P<0.00$ I vs placebo; ${ }^{*} P<0.00$ I vs exenatide. (B) AWARD-2: $*$ indicated two-sided $P<0.05$ vs glargine.

Abbreviations: AWARD, Assessment of Weekly Administration of Dulaglutide in Diabetes; HbA ${ }_{l c}$, glycated hemoglobin; Dula, dulaglutide; P, placebo; Exe, exenatide; Glar, glargine.

achieved the target $\mathrm{HbA}_{1 \mathrm{c}}$ level of $\leq 6.5 \%$ than sitagliptin $100 \mathrm{mg}$ group (19\%).

\section{AWARD-6}

At 26 weeks, the proportions of patients achieving the target $\mathrm{HbA}_{1 \mathrm{c}}$ level of $<7 \%$ were similar in dulaglutide $1.5 \mathrm{mg}$ and liraglutide $1.8 \mathrm{mg}$ groups (68\%) (Figure 6). ${ }^{20}$ However, at the same time-point, slightly more patients $(55 \%)$ in the dulaglutide $1.5 \mathrm{mg}$ group met the target $\mathrm{HbA}_{1 \mathrm{c}}$ level of $\leq 6.5 \%$ than those in the liraglutide $1.8 \mathrm{mg}$ group (51\%).

\section{Body weight changes from baseline AWARD-I}

The mean change in body weight from baseline to 26 weeks was greater with dulaglutide $1.5 \mathrm{mg}(-1.30 \mathrm{~kg}$; SD, 4.84) than with exenatide $10 \mu \mathrm{g}(-1.07 \mathrm{~kg} ; \mathrm{SD}, 4.39)(P$-value comparing the two not reported) (Figure 7). ${ }^{23}$ In contrast, those receiving dulaglutide $0.75 \mathrm{mg}$ and placebo gained weight, $4.85 \mathrm{~kg}$; SD, 0.20 and $1.24 \mathrm{~kg}$; SD, 4.39, respectively. At 52 weeks, the mean change in body weight change was greater in the $1.5 \mathrm{mg}$ dulaglutide group $(-1.01 \mathrm{~kg})$ than in 
the exenatide $10 \mu \mathrm{g}(-0.71 \mathrm{~kg})$ and the dulaglutide $0.75 \mathrm{mg}$ groups $(-0.54 \mathrm{~kg})$.

\section{AWARD-2}

At 52 weeks, the mean changes in weight with dulaglutide 1.5 and $0.75 \mathrm{mg}$ were $-1.87 \mathrm{SD} ; 3.9 \mathrm{~kg}$ and $-1.33 \mathrm{SD} ; 3.9 \mathrm{~kg}$, respectively, while those in the insulin glargine group gained weight of $1.44 \mathrm{SD} ; 3.8 \mathrm{~kg}(P<0.05$ vs glargine) (Figure 7$) .{ }^{21}$ The findings were similar at 78 weeks.

\section{AWARD-5}

At 26 weeks, mean weight reductions from baseline were significantly $(P<0.001)$ greater with both dulaglutide doses $(-3.04 \mathrm{~kg}$; SD, 3.48 with dulaglutide $1.5 \mathrm{mg} ;-2.65 \mathrm{~kg}$; SD, 3.47 with dulaglutide $0.75 \mathrm{mg}$ ) than on sitagliptin $100 \mathrm{mg}$ $\left(-1.39 \mathrm{~kg}\right.$; SD, 3.54) and placebo $\left(-1.42 \mathrm{~kg}\right.$; SD, 3.5). ${ }^{22}$ At 52 weeks, the mean changes in body weight from baseline with dulaglutide $1.5 \mathrm{mg}(-3.03 \mathrm{~kg}$; SD, 3.48) and $0.75 \mathrm{mg}$ $(-2.60 \mathrm{~kg}$; SD, 3.47) were significantly $(P<0.001)$ greater than on sitagliptin $100 \mathrm{mg}(-1.53 \mathrm{~kg}$; SD, 3.54) and placebo $(-1.42 \mathrm{~kg} ; \mathrm{SD}, 3.5)$. At 104 weeks, both dulaglutide doses (1.5 mg: $-2.88 \mathrm{~kg}$; $0.75 \mathrm{mg}:-2.39 \mathrm{~kg}$ ) showed significantly greater weight reduction $(P<0.001)$ compared to sitagliptin $100 \mathrm{mg}(-1.75 \mathrm{~kg})$ (Figure 8).

\section{AWARD-6}

The mean changes in body weight from baseline at 26 weeks were greater with liraglutide $1.8 \mathrm{mg}(-3.61 \mathrm{~kg}$; SD, 3.8) than with dulaglutide $1.5 \mathrm{mg}\left(-2.9 \mathrm{~kg}\right.$; SD, 3.8) (Figure 8). ${ }^{20}$

\section{Fasting plasma glucose and postprandial plasma glucose (FPG and PPG)}

At 26 weeks, the AWARD- $1^{23}$ trial showed significantly greater $(P<0.001)$ reductions in FPG concentration from baseline with dulaglutide $-1.5 \mathrm{mg}(-43 \mathrm{mg} / \mathrm{dL}$; SD, 33.4 or $-2.4 \mathrm{mmol} / \mathrm{L})$ and with $0.75 \mathrm{mg}(-34 \mathrm{mg} / \mathrm{dL}$; SD, 33.4 or $1.89 \mathrm{mmol} / \mathrm{L})$ than with exenatide $10 \mu \mathrm{g}(-24 \mathrm{mg} / \mathrm{dL} ; \mathrm{SD}$, 33.4 or $1.33 \mathrm{mmol} / \mathrm{L})$ and placebo $(-5 \mathrm{mg} / \mathrm{dL}$; SD, 35 or $0.28 \mathrm{mmol} / \mathrm{L}$ ) (Table 3 ). At 52 weeks, both dulaglutide doses significantly reduced mean FPG $(1.5 \mathrm{mg}: P<0.001 ; 0.75 \mathrm{mg}$ : $P=0.005$ ) when compared with exenatide $10 \mu \mathrm{g}$.

The mean eight-point self-monitored plasma glucose profiles showed greater reductions with both dulaglutide 1.5 and $0.75 \mathrm{mg}(P<0.001)$ than with placebo and exenatide. PPG also showed greater reductions with all active treatment groups $(P<0.001$ compared with placebo; for dulaglutide $1.5 \mathrm{mg}$ vs exenatide $10 \mu \mathrm{g}, P=0.047)$. Similar reductions were reported for 2-hour PPG by patients on dulaglutide $1.5 \mathrm{mg}$
$(P=0.003)$ and exenatide $10 \mu \mathrm{g}(P<0.001)$ compared with placebo. The excursions of postprandial glucose after midday and evening meal were greater with dulaglutide compared to exenatide. The changes were greater with dulaglutide groups than $(P<0.001)$ with exenatide $10 \mu \mathrm{g}$ (only $P$-value reported, data not reported).

\section{AWARD-2 trials did not report FPG and PPG}

In the AWARD-5 trial, ${ }^{22}$ FPG reductions were higher with both dulaglutide doses (no data provided, but values read from Figure $2 \mathrm{D}$ and are approximate; $1.5 \mathrm{mg}$ dulaglutide: $-45 \mathrm{mg} / \mathrm{dL}$ or $-2.5 \mathrm{mmol} / \mathrm{L}$; $0.75 \mathrm{mg}$ dulaglutide: $-37 \mathrm{mg} / \mathrm{dL}$ or $-2.06 \mathrm{mmol} / \mathrm{L}$ ) than with sitagliptin $100 \mathrm{mg}(-20 \mathrm{mg} / \mathrm{dL}$ or $-1.11 \mathrm{mmol} / \mathrm{L})$ and placebo $(-10 \mathrm{mg} / \mathrm{dL}$ or $-0.56 \mathrm{mmol} / \mathrm{L})$ at 26 weeks. ${ }^{21}$ At 52 weeks, the reduction was greater with both dulaglutide $(P<0.001)$ than with sitagliptin $100 \mathrm{mg}(1.5 \mathrm{mg}$ dulaglutide: $-45 \mathrm{mg} / \mathrm{dL}$ or $-2.5 \mathrm{mmol} / \mathrm{L} ; 0.75 \mathrm{mg}$ dulaglutide: $-30 \mathrm{mg} / \mathrm{dL}$ or $-1.67 \mathrm{mmol} / \mathrm{L}$; sitagliptin: $-20 \mathrm{mg} / \mathrm{dL}$ or $-1.11 \mathrm{mmol} / \mathrm{L})$.

The AWARD-6 trial ${ }^{20}$ reported that at 26 weeks both dulaglutide $1.5 \mathrm{mg}(-1.93 \mathrm{mmol} / \mathrm{L})$ and liraglutide $1.8 \mathrm{mg}$ $(-1.90 \mathrm{mmol} / \mathrm{L})$ reduced the FPG concentration with no significant difference between the two (difference of -0.03 , $P=0.83$ ). Similarly, there was no difference between the two in terms of PPG (Table 3).

\section{Blood pressure}

AWARD 1, 5, and 6 reported on systolic blood pressure (SBP) (Table 3). The reduction in SBP was slightly greater with dulaglutide $1.5 \mathrm{mg}(-3.36 \mathrm{mmHg})$ than with liraglutide $1.8 \mathrm{mg}(-2.82 \mathrm{mmHg})$. In AWARD-1, SBP increased in patients on the higher dose of dulaglutide $(+0.11 \mathrm{mmHg})$ and on exenatide $10 \mu \mathrm{g}(0.06 \mathrm{mmHg})$, whereas, SBP reduced in those taking lower dose of dulaglutide $(-0.36 \mathrm{mmHg})$. At 26 weeks, the reductions in SBP were similar in those taking sitagliptin $100 \mathrm{mg}(-1.9 \mathrm{mmHg})$ and dulaglutide $(-1.7 \mathrm{mmHg}$ with dulaglutide $1.5 \mathrm{mg} ;-1.4 \mathrm{mmHg}$ with dulaglutide $0.75 \mathrm{mg}$ ). Data for AWARD-2 trial $^{17}$ were not available.

\section{Hypoglycemia}

All four trials defined "total hypoglycemia" or "hypoglycemia" as a PG level of $\leq 70 \mathrm{mg} / \mathrm{dL}(\leq 3.9 \mathrm{mmol} / \mathrm{L})$ with or without symptoms or signs attributable to hypoglycemia, and defined "severe hypoglycemia" as an episode requiring help of another person.

Total hypoglycemia (as defined above) was slightly more common ( $9 \%$ vs $6 \%$ ) on dulaglutide than on liraglutide $1.8 \mathrm{mg}$ 
Table 2 Changes in $\mathrm{HbA}_{1 \mathrm{c}}$, weight and $\mathrm{BMI}$

\begin{tabular}{|c|c|c|c|c|}
\hline Study & $\begin{array}{l}\text { HbA } \text { Ic }_{\text {(change }} \\
\text { from baseline) }\end{array}$ & $P$-value & $\begin{array}{l}\mathrm{HbA}_{\mathrm{Ic}}<7 \% \text { (change } \\
\text { from baseline \%) }\end{array}$ & $P$-value \\
\hline \multicolumn{5}{|c|}{ Dula I.5/0.75/exe/placebo } \\
\hline Wysham et $\mathrm{a}^{23}$ & 26 weeks: & 26 weeks: & 26 weeks: & 26 weeks: \\
\hline \multirow[t]{8}{*}{ AWARD-I } & Dula I.5: $-1.51 \%$, SD 1.002 & Dula I. 5 and 0.75 : adjusted one-sided & Dula I.5: 218 (78.2) & Dula I.5 and 0.75 : \\
\hline & Dula $0.75:-1.3 \%$, SD 1.003 & $P<0.00$ I for superiority, vs Exe or $P$ & Dula 0.75: $184(65.8)$ & two-sided $P<0.05$ vs $P$ \\
\hline & Exe: $-0.99 \%$, SD 0.99 & respectively, for $\mathrm{HbA}_{\mathrm{Ic}}$ change only & Exe: I $44(52.3)$ & two-sided $P<0.05$ vs Exe \\
\hline & P: $-0.46 \%$, SD 0.94 & Exe: two-sided $P<0.05$ vs $P$ & P: 60 (42.9) & Exe: 2 sided $P<0.05$ vs $P$ \\
\hline & 52 weeks: & 52 weeks: & 52 weeks: & 52 weeks: \\
\hline & Dula I.5: $-1.36 \%$, SD I.33 & Dula 1.5 and $0.75:$ adjusted & Dula I.5: 197 (70.8) & Dula I.5 and $0.75:$ \\
\hline & Dula $0.75:-1.07 \%$, SD 1.33 & one-sided $P<0.00$ I for superiority, vs & Dula 0.75: $165(59.1)$ & two-sided $P<0.05$ vs Exe \\
\hline & Exe: $-0.80 \%$, SD 1.32 & Exe for $\mathrm{HbA}$ change only & Exe: $136(49.2)$ & \\
\hline \multicolumn{5}{|c|}{ Dula $1.5 / 0.75 \mathrm{mg} /$ glargine } \\
\hline Giorgino & 52 weeks: & Dula I.5: adjusted $P<0.00$ I & 52 weeks: & (Two-sided $P<0.05$ vs \\
\hline et $\mathrm{al}^{21}$ AWARD-2 & Dula I.5: $-1.08 \%$, SD 0.9 & for superiority vs glargine & Dula I.5: I 45 (53.2) & glargine) \\
\hline \multirow[t]{6}{*}{ (abstract) } & Dula $0.75: 0 \%-0.76 \%$, SD 0.9 & for $A_{I c}$ change & Dula 0.75: 101 (37.I) & Two-sided $P<0.05$ vs \\
\hline & Glar: $0.63 \%$, SD 0.9 & Dula 0.75: adjusted $P<0.00$ I & Glar: 81 (30.9) & glargine \\
\hline & 78 weeks: & for nonsuperiority vs glargine & 78 weeks: & \\
\hline & Dula I.5: $-0.9 \%$, SD I.I & for $A_{I c}$ change & Dula I.5: I 34 (49) & \\
\hline & Dula $0.75:-0.62 \%$, SD I.I & & Dula 0.75: $93(34.1)$ & \\
\hline & Glar: $-0.59 \%$, SD I.I & & Glar: $80(30.5)$ & \\
\hline \multicolumn{5}{|c|}{ Dula $1.5 / 0.75 \mathrm{mg} / \mathrm{sita} /$ placebo } \\
\hline Nauck et $\mathrm{al}^{22}$ & 26 weeks: & 26 weeks: & 26 weeks: & 26 weeks: \\
\hline \multirow[t]{13}{*}{ AWARD-5 } & Dula I.5: $-1.22 \%$, SD 0.87 & Dula I. 5 and 0.75 : adjusted & Dula I.5: I85 (6I) & Dula I.5 and 0.75: \\
\hline & Dula $0.75:-1.01 \%$, SD 1.04 & one-sided $P<0.001$ for & Dula 0.75: 167 (55.2) & two-sided $P<0.001$ vs $P$ \\
\hline & Sita: $-0.61 \%$, SD 0.88 & superiority vs $P$ for $A_{I c}$ change & Sita: $119(37.8)$ & Two-sided $P<0.001$ vs \\
\hline & (two-sided $P<0.00$ I vs $P$ ) & Two-sided $P<0.001$ vs sita & P: $37(2 I)$ & sita \\
\hline & P: $0.03 \%$, SD 0.93 & 52 weeks: & 52 weeks: & 52 weeks: \\
\hline & 52 weeks: & Dula 1.5 and $0.75:$ adjusted & Dula I.5: I 75 (57.6) & Dula I.5 and $0.75:$ \\
\hline & Dula I.5: -I.I\%, SD I.04 & one-sided $P<0.00$ I for superiority vs & Dula 0.75: I 47 (48.8) & two-sided $P<0.001$ vs sita \\
\hline & Dula $0.75:-0.87 \%$, SD I.04 & Sita for $A_{I c}$ change & Sita: $104(33)$ & I04 weeks: \\
\hline & Sita: $-0.39 \%$, SD I.06 & I04 weeks: & 104 weeks: & Dula I.5 and $0.75:$ \\
\hline & 104 weeks: & Dula 1.5 and $0.75:$ adjusted & Dula I.5: I65 (54.3) & two-sided $P<0.00$ I vs sita \\
\hline & Dula I.5: -I\%, SD I.04 & one-sided $P<0.00$ I for superiority vs & Dula 0.75: $135(44.8)$ & \\
\hline & Dula $0.75:-0.71 \%$, SD I.2 & Sita for $A_{I c}$ change only & Sita: $98(31.1)$ & \\
\hline & Sita: $0.32 \%$, SD I.06 & & & \\
\hline \multicolumn{5}{|l|}{ Dula/lira } \\
\hline Dungan et $\mathrm{a}^{20}$ & 26 weeks: & From baseline: $<0.000 \mathrm{I}$ & 26 weeks: & Not given \\
\hline \multirow[t]{4}{*}{ (AWARD-6) } & Dula: $-1.4 \%$, SD 0.86 & From baseline: $<0.000 \mathrm{I}$ & Dula: 200/293 (68) & \\
\hline & Lira: $-1.36 \%$, SD 0.86 & Difference between groups ( $95 \%$ & Lira: 199/293 (68) & \\
\hline & & $\mathrm{Cl}):-0.06 \%(-0.19$ to 0.07$) P \leq 0.000$ & & \\
\hline & & (noninferiority of dula vs lira) & & \\
\hline \multicolumn{5}{|c|}{ Bain $2014^{44}$ (abstract) post hoc analysis at 26 weeks to determine the influence of baseline HbA $A_{I c}$ in the AWARD-I trial } \\
\hline & & Baseline $<8.5 \% \quad$ B & Baseline $\geq 8.5 \%$ & $P$-value \\
\hline Dula $1.5 \mathrm{mg}$ & & $-1.16(0.07) \%$ & $-2.37(0.10) \%$ & $<0.00 \mathrm{I}$, all comparisons \\
\hline Placebo & & $0.17(0.10) \%$ & $-0.76(0.16) \%$ & \\
\hline Exenatide $10 \mu \mathrm{g}$ & & $-0.64(0.07) \%$ & $-1.86(0.11) \%$ & \\
\hline \multicolumn{5}{|c|}{ Proportion of patients achieving $\mathrm{HbA}_{\mathrm{Ic}}$ targets } \\
\hline \multirow{2}{*}{\multicolumn{5}{|c|}{ Dula $1.5 \mathrm{mg}$}} \\
\hline $\begin{array}{l}\text { Dula } 1.5 \mathrm{mg} \\
<7 \%\end{array}$ & & & $47 \%$ & \\
\hline $\begin{array}{l}<7 \% \\
\leq 6.5\end{array}$ & & $\begin{array}{l}92 \% \\
80 \%\end{array}$ & $\begin{array}{l}47 \% \\
26 \%\end{array}$ & $<0.05$, all comparisons \\
\hline \multicolumn{5}{|l|}{$\begin{array}{r}\leq 6.5 \\
\text { Placebo }\end{array}$} \\
\hline \multicolumn{5}{|l|}{$<7 \%$} \\
\hline$\leq 6.5$ & & $32 \%$ & $3 \%$ & \\
\hline \multicolumn{5}{|l|}{ Exe } \\
\hline$<7 \%$ & & $65 \%$ & $21 \%$ & \\
\hline$\leq 6.5$ & & $50 \%$ & $9 \%$ & \\
\hline \multicolumn{4}{|c|}{ Dula $0.75 \mathrm{mg}$ reported significant changes for both baseline groups vs placebo } & $<0.05$, both outcomes, \\
\hline \multirow{2}{*}{\multicolumn{4}{|c|}{ Dula $0.75 \mathrm{mg}$ with exenatide $10 \mu \mathrm{g}$ in the baseline $\mathrm{HbA}_{\mathrm{Ic}} \geq 8.5 \%$ groups }} & all comparisons \\
\hline & & & & Statistically not significant \\
\hline
\end{tabular}




\begin{tabular}{|c|c|c|c|c|}
\hline $\begin{array}{l}\mathrm{HbA}_{\mathrm{Ic}}<6.5 \% \text { (change } \\
\text { from baseline) }\end{array}$ & $P$-value & $\begin{array}{l}\text { Weight change from } \\
\text { baseline (kg) }\end{array}$ & $P$-value & BMI \\
\hline 26 weeks: & $P<0.00$ I all comparisons & 26 weeks: & 26 weeks: & Not given \\
\hline Dula I.5: 176 (63) & Not given & Dula I.5: -I.30, SD 4.84 & Dula I.5: two-sided $P<0.05$ vs $P$ & \\
\hline Dula 0.75: I 48 (53) & & Dula 0.75: 0.20, SD 4.85 & Dula 0.75: two-sided $P<0.05$ vs & \\
\hline Exe: $105(38)$ & & Exe: -1.07, SD 4.39 & Exe and $P$ & \\
\hline P: $34(24)$ & & P: 1.24, SD 4.39 & 52 weeks: & \\
\hline 52 weeks: & & 52 weeks: & Dula 0.75: two-sided $P<0.05$ vs Exe & \\
\hline Dula I.5: $57 \%$ & & Dula I.5: -1.0I, SD 6.3 & & \\
\hline Dula $0.75: 48 \%$ & & Dula 0.75: 0.54, SD 6.3 & & \\
\hline Exe: $35 \%$ & & Exe: $-0.7 \mathrm{I}, \mathrm{SD} 6.3 \mathrm{I}$ & & \\
\hline Not given & & $\begin{array}{l}52 \text { weeks: } \\
\text { Dula I.5: - I.87, SD } 3.9 \\
\text { Dula 0.75: -I.33, SD } 3.9 \\
\text { Glar: I.44, SD } 3.8 \\
78 \text { weeks: } \\
\text { Dula I.5: - I.96, SD } 4.2 \\
\text { Dula } 0.75:-1.54, \text { SD } 4.2 \\
\text { Glar: +I.28, SD } 4.2\end{array}$ & Two-sided $P<0.05$ vs glargine & $\mathrm{N} / \mathrm{A}$ \\
\hline 26 weeks: & $P<0.00$ I, both comparisons & 26 weeks: & 26 weeks: & Not given \\
\hline Dula I.5: I 43 (47) & $(P<0.00$ I both dula & Dula I.5: -3.04, SD 3.48 & Dula I.5 and 0.75: two-sided & \\
\hline Dula 0.75: $94(3 \mathrm{I})$ & comparisons; $P=0.005$ & Dula $0.75:-2.65$, SD 3.47 & $P<0.001$ vs $P$ & \\
\hline Sita: 69 (22) & sita comparison) & Sita: -I.39, SD 3.54 & Two-sided $P<0.00$ I vs sita & \\
\hline P: $23(13)$ & $P \leq 0.00$ I vs sita, both & $P:-1.42$, SD 3.5 & 52 weeks: & \\
\hline 52 weeks: & comparisons & 52 weeks: & Dula I.5 and 0.75: two-sided & \\
\hline Dula I.5: I 28 (42) & & Dula I.5: -3.03 , SD 3.83 & $P<0.00$ I vs sita & \\
\hline Dula 0.75: 88 (29) & & Dula 0.75: -2.6 , SD 3.9 & I04 weeks: & \\
\hline Sita: 60 (19) & & Sita: -1.53, SD 3.9 & Dula 1.5: two-sided $P<0.001$ vs sita & \\
\hline 104 weeks: & & I04 weeks: & Dula 0.75 : two-sided $P=0.054$ vs sita & \\
\hline \multirow[t]{3}{*}{ Not given } & & Dula I.5: -2.88, SD 4.3 & & \\
\hline & & Dula $0.75:-2.39$, SD 4.5 & & \\
\hline & & Sita: -1.75, SD 4.4 & & \\
\hline 26 weeks: & & 26 weeks: & From baseline $P<0.000 \mathrm{I}$ & Consistent \\
\hline Dula: 169 (55\%) & & Dula: -2.9, SD 3.88 & From baseline $P<0.0001$ & with weight \\
\hline Lira: 149 (5 I\%) & & Lira: -3.6I, SD 3.8 & $\begin{array}{l}\text { Difference between groups } \\
(95 \% \mathrm{Cl}) \text { : } 0.7 \mathrm{I}(0.17-\mathrm{I} .26) P=0.01 \mathrm{I}\end{array}$ & finding \\
\hline
\end{tabular}

Abbreviations: AWARD, Assessment of Weekly Administration of Dulaglutide in Diabetes; HbA Glar, glargine; Sita, sitagliptin; Lira, liraglutide; BMI, body mass index; N/A, not available; SD, standard deviation; Cl, confidence interval. 
A

AWARD-5
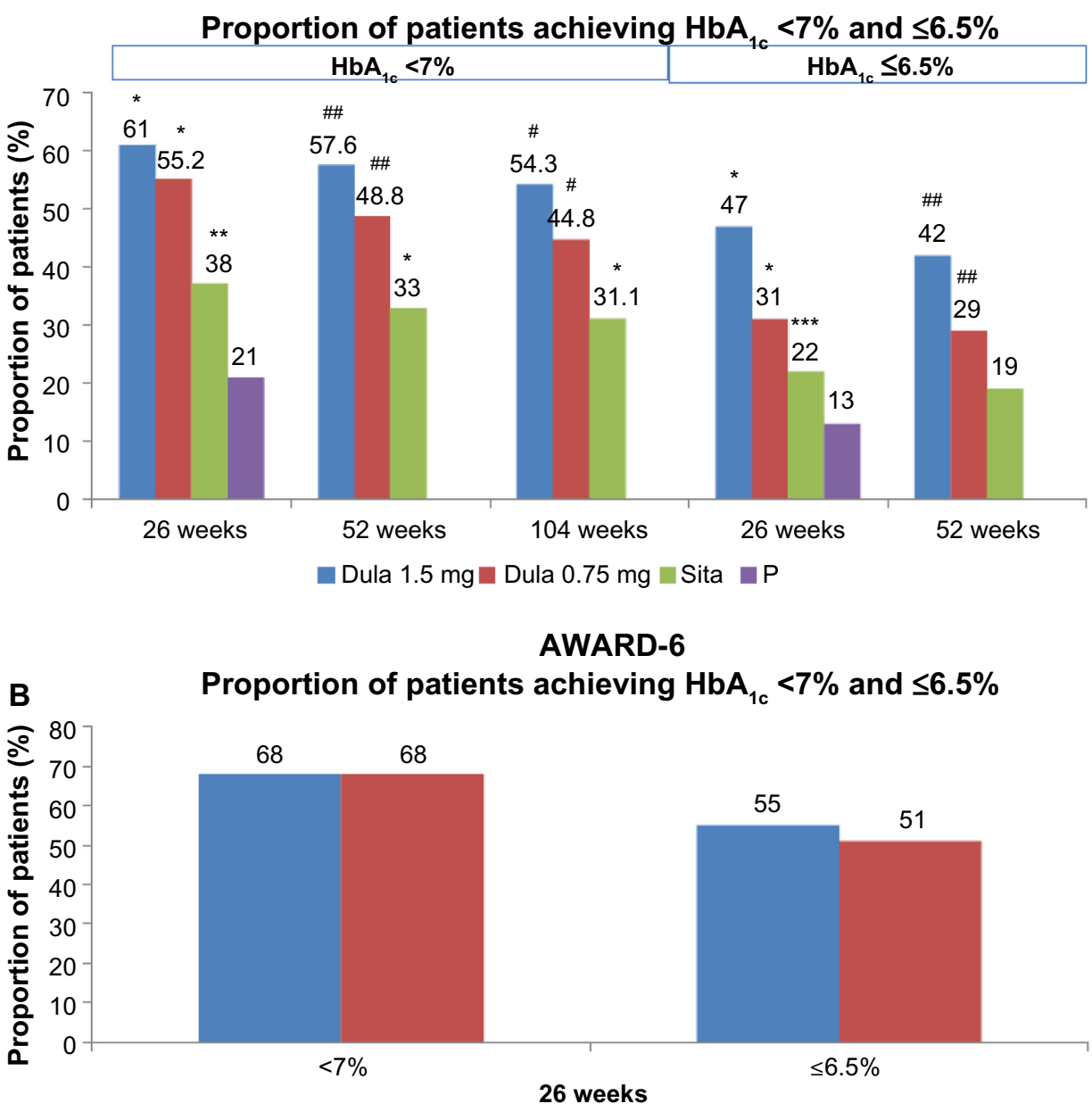

Dula $1.5 \mathrm{mg}$ Lira $1.8 \mathrm{mg}$

Figure 6 (A) and (B) Proportion of patients achieving a target $\mathrm{HbA}_{\mathrm{lc}}$ level of $<7 \%$ and $\leq 6.5 \%$ (AWARD 5 and 6 ).

Notes: AWARD-5: $* P<0.001$ vs sitagliptin and placebo; ${ }^{*} P<0.001$ vs placebo; ${ }^{* * *} P<0.001$ vs sitagliptin; ${ }^{*} P<0.05$ vs sitagliptin; ${ }^{\#} P<0.00$ I vs sitagliptin.

Abbreviations: AWARD, Assessment of Weekly Administration of Dulaglutide in Diabetes; HbA ${ }_{1 c}$, glycated hemoglobin; Dula, dulaglutide; P, placebo; Sita, sitagliptin; Lira, liraglutide.

(AWARD-6) ( $P$-value not reported). ${ }^{20}$ In AWARD-5, ${ }^{22}$ the incidence of hypoglycemia at 52 weeks was significantly higher in dulaglutide $1.5 \mathrm{mg}$ than in sitagliptin $100 \mathrm{mg}$ ( 0.4 events/ patient/year vs 0.1 events/patient/year, $P$-value not reported), whereas the incidence was similar at 26 weeks. In AWARD- $1,{ }^{23}$ more patients in the exenatide $10 \mu \mathrm{g}$ arm (16\%) experienced hypoglycemia $(P<0.007)$ than in the two dulaglutide arms (1.5 and $0.75 \mathrm{mg}$ ) at 26 weeks ( $10 \%$ and $11 \%$, respectively). The incidence of hypoglycemia was reported to be lower in the dulaglutide arms $(1.5 \mathrm{mg})$ compared to exenatide $10 \mu \mathrm{g}$ arm at 52 weeks, but no data were reported. At 78 weeks, patients in both dulaglutide arms $(1.7 \mathrm{mg}, 1.7 \mathrm{mg}$ ) had lower rates of hypoglycemia compared to glargine 3.0 events/patient/year $(P \leq 0.002)\left(\right.$ AWARD-2). ${ }^{21}$

Severe hypoglycemia was seen only in a few patients in both dulaglutide and glargine arms in AWARD-2, it was not reported whether they were also on an SU.

\section{Adverse events}

Details of the adverse events are shown in Table 4. The most commonly reported adverse events in all trials were nausea, vomiting, and diarrhea, which were significantly more common in the GLP-1-treated groups than in placebo-treated groups. Discontinuation in the trials due to adverse events was also higher in all the actively treated groups, and the main reasons for discontinuation were nausea in AWARD 1, 6, and $5^{19,20,23}$ and hyperglycemia in AWARD-5. ${ }^{19}$ The numbers of patients with severe adverse events were similar across all actively treated groups.

Deaths were reported by AWARD 5 and $1 .{ }^{22,23}$ In AWARD- $5^{22}$, four patients died - one patient in dulaglutide $1.5 \mathrm{mg}$ arm (due to nonhemorrhagic stroke 6 months postrandomization), one in sitagliptin $100 \mathrm{mg}$ arm (cause of death not reported), and two patients in placebo arm (cause of death not reported). In AWARD- $1,{ }^{23}$ four patients 

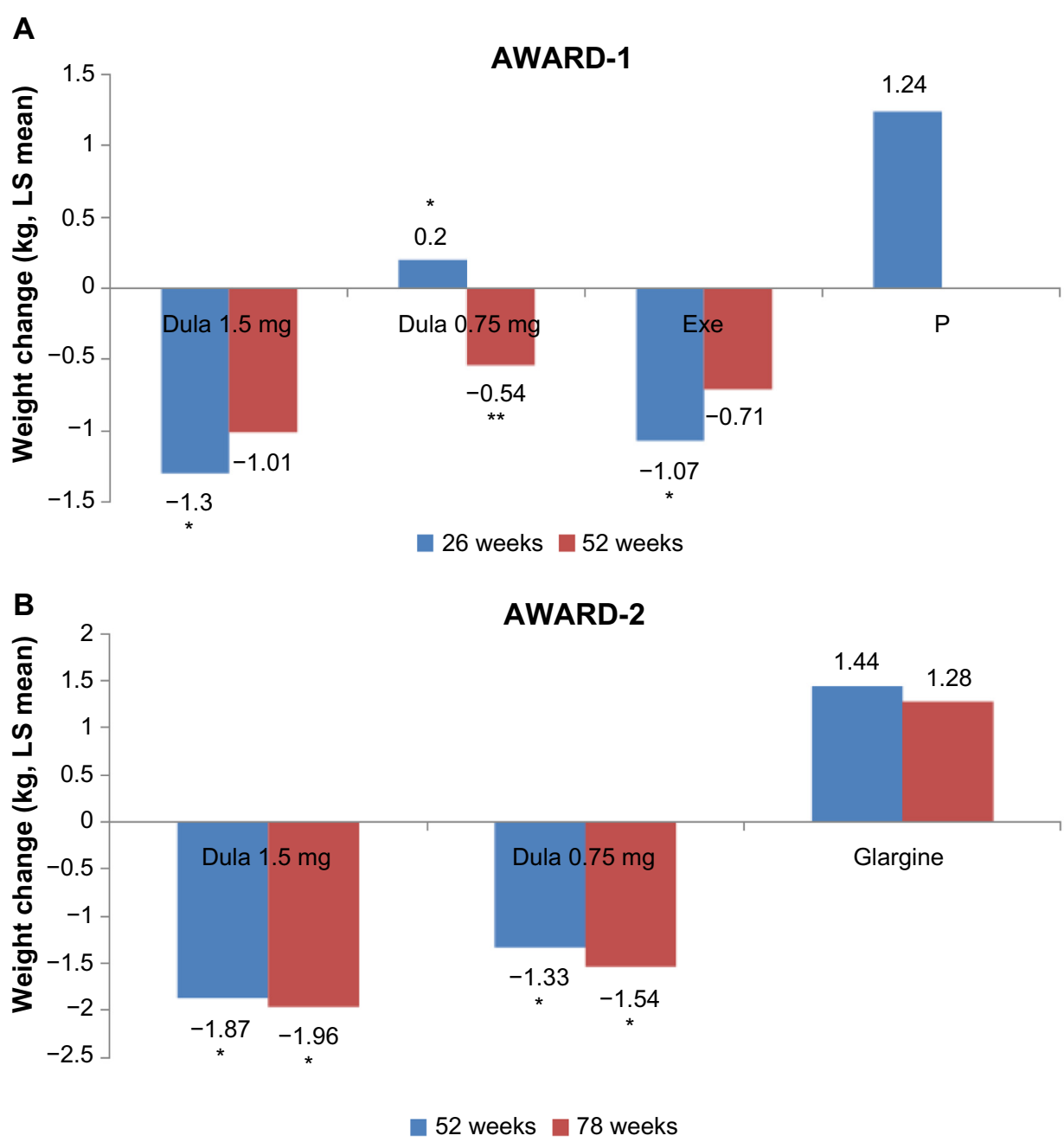

Figure 7 Mean change in weight $(\mathrm{kg})$ from baseline to follow-up (AWARD I and 2).

Notes: (A) AWARD-I: * two-sided $P<0.05$ vs placebo; ** two-sided $P<0.05$ vs exenatide. (B) AWARD-2: *two-sided $P<0.05$ vs glargine.

Abbreviations: LS, least square; AWARD, Assessment of Weekly Administration of Dulaglutide in Diabetes; Dula, dulaglutide; Exe, exenatide; P, placebo.

died - two patients in each dulaglutide arm $1.5 \mathrm{mg}$ (one due to myocardial infarction at around 13 weeks after randomization and one patient died due to pancreatic cancer 9 months after discontinuing dulaglutide, which the patient took for about 6 months) and $0.75 \mathrm{mg}$ (one died at around 14 weeks after randomization due to natural causes, but had a history of cardiovascular risk factors and cause of death in one patient not reported), respectively.

Three cases of acute pancreatitis were reported in AWARD-5, ${ }^{22}$ two patients on sitagliptin $100 \mathrm{mg}$ and one patient on placebo/sitagliptin $100 \mathrm{mg}$ (while on sitagliptin), while none of the patients receiving the two dulaglutide doses developed pancreatitis. No cases of pancreatic cancer or pancreatitis were reported in AWARD- $6 .^{20}$ One patient receiving liraglutide in AWARD-6 was diagnosed with papillary thyroid carcinoma, but none in the dulaglutide group. None of the patients developed C-cell hyperplasia or medullary thyroid carcinoma (MTC). In AWARD- $1,{ }^{23}$ one patient in the dulaglutide $1.5 \mathrm{mg}$ arm was diagnosed with chronic pancreatitis 7 months after study drug initiation, and one patient on dulaglutide $1.5 \mathrm{mg}$ for 6 months was diagnosed with pancreatic cancer and died at 9 months after study discontinuation.

The trials in total involved 3,048 patients followed for at most 78 weeks, and longer follow-up with larger numbers will be necessary to provide safety data.

\section{Discussion}

This review included four Phase III studies. The AWARD-2 $2^{21}$ study was available only as an abstract, while all the remaining three trials were published in full. The comparisons were dulaglutide $1.5 \mathrm{mg}$ vs liraglutide $1.8 \mathrm{mg}$ (AWARD-6) add on to metformin, dulaglutide $(1.5 / 0.75 \mathrm{mg})$ vs glargine (AWARD-2) add on to metformin and SU, dulaglutide (1.5/0.75 mg) vs sitagliptin $100 \mathrm{mg}$ and placebo (AWARD-5) add on to metformin, and AWARD-1 had dulaglutide 

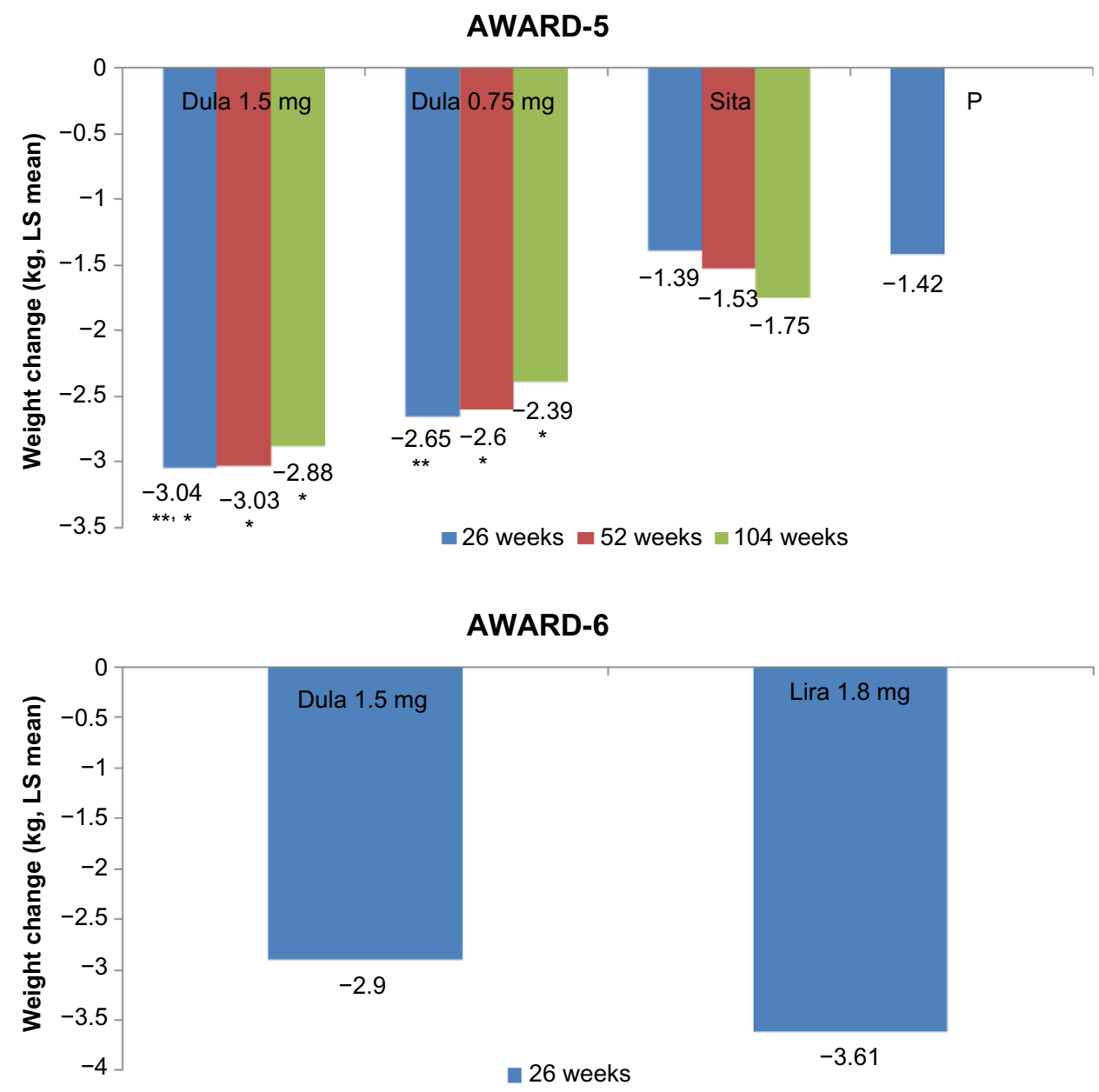

Figure 8 Mean change in weight $(\mathrm{kg})$ from baseline to follow-up (AWARD 5 and 6).

Notes: AWARD-5: *two-sided $P<0.001$ vs sitagliptin; **two-sided $P<0.001$ vs placebo.

Abbreviations: LS, least square; AWARD, Assessment of Weekly Administration of Dulaglutide in Diabetes; Dula, dulaglutide; P, placebo; Sita, sitagliptin; Lira, liraglutide.

$(1.5 / 0 / 75 \mathrm{mg})$ vs exenatide $10 \mu \mathrm{g}$ twice daily and placebo add on to metformin and thiazolidinediones. All trials were funded by Eli Lilly.

\section{Summary of principal findings}

The results suggested that dulaglutide is effective in improving glycemic control and promoting weight loss, with a low risk of hypoglycemia.

\section{$\mathrm{HbA}_{\mathrm{lc}}$}

Both doses of dulaglutide were reported to show noninferiority against liraglutide $1.8 \mathrm{mg}$, while dulaglutide was found to be superior to sitagliptin $100 \mathrm{mg}$ by $0.71 \%$ ( $1.5 \mathrm{mg}$ dulaglutide) to $0.48 \%$ ( $0.75 \mathrm{mg}$ dulaglutide), respectively. $\mathrm{HbA}_{1 \mathrm{c}}$ change was greater with $1.5 \mathrm{mg}$ dulaglutide than with glargine; however, the reduction with $0.75 \mathrm{mg}$ dulaglutide was nonsuperior against glargine.
$\mathrm{HbA}_{\text {Ic }}$ target of $<7 \%$ and $\leq 6.5 \%$

The proportions of patients who achieved $\mathrm{HbA}_{1 \mathrm{c}}$ targets of $<7 \%$ and $\leq 6.5 \%$ were reported to be significantly higher among dulaglutide-treated patients compared to exenatide $10 \mu \mathrm{g}$ twice daily, sitagliptin $100 \mathrm{mg}$, liraglutide $1.8 \mathrm{mg}$, and glargine. Separate post hoc analysis conducted for subgroups according to baseline $\mathrm{HbA}_{1 \mathrm{c}}$ levels of $<8.5 \%$ and $\geq 8.5 \%$ found that greater proportions of patients reached targets of $<7 \%$ and $\leq 6.5 \%$, irrespective of their baseline $\mathrm{HbA}_{1 \mathrm{c}}$ level, on dulaglutide than on placebo and exenatide $10 \mu \mathrm{g}$.

\section{Weight loss}

The results varied among studies. Dulaglutide led to greater reduction in weight compared to sitagliptin 100 $\mathrm{mg}$ and exenatide $10 \mu \mathrm{g}$. In contrast, patients receiving liraglutide $1.8 \mathrm{mg}$ lost more weight than those receiving dulaglutide $1.5 \mathrm{mg}$ in AWARD-6. The weight reductions 
with dulaglutide in AWARD-6 and AWARD-1 trials differed. In the former, at 26 weeks, the reduction with dulaglutide $1.5 \mathrm{mg}$ was $2.9 \mathrm{~kg}$, while in the latter, at the same time-point, the reduction was only $1.3 \mathrm{~kg}$. At baseline, mean BMIs (33.5-33.6 kg/m² in AWARD-6; 33-34 kg/m² in AWARD-1) and mean weight were similar (93.8-94.4 kg in AWARD-6; 94-96 kg in AWARD-1) in the two trials; therefore, it was not clear why there was a difference between the two studies. Mean duration of diabetes in AWARD-1 was slightly greater than in AWARD-6 (9 vs 7 years).

\section{Hypoglycemia and adverse events}

The incidence of hypoglycemia was low with dulaglutide, and there were few cases of severe hypoglycemia with dulaglutide and glargine. The main adverse effects of dulaglutide were nausea, diarrhea, and vomiting. There was one report of death due to pancreatic cancer 9 months after discontinuing treatment with dulaglutide (6 months therapy) in AWARD-1. No other cases of pancreatic cancer or adjudicated pancreatitis were reported in other AWARD trials.

\section{Strengths and limitations}

The review followed a systematic approach to identify and appraise all the relevant papers on the effectiveness of dulaglutide in patients with type 2 diabetes mellitus, who are not achieving satisfactory glycemic control with "combinations of oral glucose-lowering drugs, or such combinations with basal insulin". All the included studies are RCTs comparing dulaglutide against placebo or against active treatments (such as other GLP-1 agonists). All but one of the articles included in the review were published in full. One was published as an abstract, but was included since there was adequate information on design and quality ${ }^{25}$ with results on secondary outcomes. We excluded studies where dulaglutide was used in treatment of naïve patients, to reflect clinical practice as patients would be treated with a cheaper oral hypoglycemic agent such as metformin before expensive injectable drugs like the GLP-1 receptor agonists are prescribed.

\section{Limitations of the review}

AWARD 2 and 6 included in the review were of open-label design. The treatment allocation was not blinded to participants, physicians, investigators, and site staff; therefore, there could be some risk of observer bias. The review did not undertake an indirect comparison or network meta-analyses to compare efficacy and safety of dulaglutide against other GLP-1 receptor agonists and other glucose-lowering drugs.
Three trials where dulaglutide was used as monotherapy were not included in the review because of our inclusion/ exclusion criteria. AWARD-3 compared dulaglutide $1.5 \mathrm{mg}$ against metformin in patients naïve to treatment. ${ }^{26}$ The study by Grunberger et $\mathrm{al}^{27}$ compared dulaglutide $(0.1,0.5,1.0$, $1.5 \mathrm{mg}$ ) vs placebo in patients naïve to treatment. Another monotherapy study by Terauchi et $\mathrm{al}^{28}$ compared dulaglutide $(0.25,0.5$, or $0.75 \mathrm{mg})$ against placebo in patients with type 2 diabetes, who were treated with diet/exercise or oral antidiabetic drug.

The AWARD-4 trial was also excluded from the review because the study compared dulaglutide against glargine, both combined with mealtime insulin lispro with or without metformin in type 2 diabetes uncontrolled on conventional insulin therapy. ${ }^{24}$

One notable thing in the AWARD study comparing dulaglutide against sitagliptin was the small reduction in $\mathrm{HbA}_{1 \mathrm{c}}$ with sitagliptin $(-1.1 \%$ with dulaglutide $1.5 \mathrm{mg},-0.86 \%$ with dulaglutide $0.75 \mathrm{mg}$, and $-0.39 \%$ with sitagliptin $100 \mathrm{mg}$ ). This is lower than seen in other trials of sitagliptin. ${ }^{29,30}$

The question still remains as to how effective dulaglutide is against other GLP-1 preparations which are used onceweekly like long-acting exenatide. Unfortunately, there is no trial comparing these drugs. The relative efficacy of dulaglutide against other GLP-1 receptor agonists could have been assessed using an indirect comparison, but this was outside the remit of this review. Also using indirect comparison methods, the efficacy and safety of this drug could have been compared against the new class of oral hypoglycemic drugs, SGLT2 inhibitors (such as dapagliflozin, canagliflozin, and empagliflozin), but since these are oral and less expensive, one would expect them to be used before GLP-1 receptor agonists. The SGLT2 inhibitors reduce blood glucose level by reducing the absorption of glucose in the kidneys.

Although dulaglutide appears to be clinically effective, the price of the drug is not yet known, and it remains to be seen whether it will be cost-effective. However, it is available in a ready to use pen compared to other GLP-1 receptor agonists, therefore there is no need to handle the needle and premix the drug, which may increase patient compliance, but it remains to be seen. In the UK, the NICE uses a cost-effectiveness threshold of $£ 20,000-£ 30,000$ per quality-adjusted life year (QALY), and a drug with costs per QALY which falls below this threshold is considered to be cost-effective and is usually accepted. The risk of developing thyroid and pancreatic cancers requires monitoring, but is unproven since the trials are not long enough. 
Table 3 Fasting plasma glucose, postprandial plasma glucose, and blood pressure

\begin{tabular}{|c|c|c|c|}
\hline Study & $\begin{array}{l}\text { FPG (change from } \\
\text { baseline) } \mathrm{mmol} / \mathrm{L}\end{array}$ & $P$-value & PPG (change from baseline) $\mathrm{mmol} / \mathrm{L}$ \\
\hline \multicolumn{4}{|c|}{ Dula I.5/0.75/exe/placebo } \\
\hline $\begin{array}{l}\text { Wysham et } \mathrm{al}^{23} \\
\text { AWARD-I }\end{array}$ & $\begin{array}{l}26 \text { weeks: } \\
\text { Dula I.5: }-43, \text { SD } 33.4 \\
\text { Dula } 0.75:-34, \text { SD } 33.4 \\
\text { Exe: }-24, \text { SD } 33.4 \\
\text { P: }-5 \text {, SD } 35 \\
52 \text { weeks: } \\
\text { Both dula arms continued with } \\
\text { significantly greater changes from } \\
\text { baseline in FSG compared with } \\
\text { exenatide } 10 \mu g(P<0.001, \text { dula } \\
\text { I. } 5 \mathrm{mg} ; P=0.005, \text { dula } 0.75 \mathrm{mg})\end{array}$ & $\begin{array}{l}\text { Mean difference } \\
\text { between dula } 1.5 \mathrm{mg} \\
\text { and } 0.75 \mathrm{mg} \text { vs exe } \\
-18 \mathrm{mg} / \mathrm{dL} \text { and } \\
-10 \mathrm{mg} / \mathrm{dL} \text { ( } P<0.00 \mathrm{I} \text {, } \\
\text { both comparisons) }\end{array}$ & 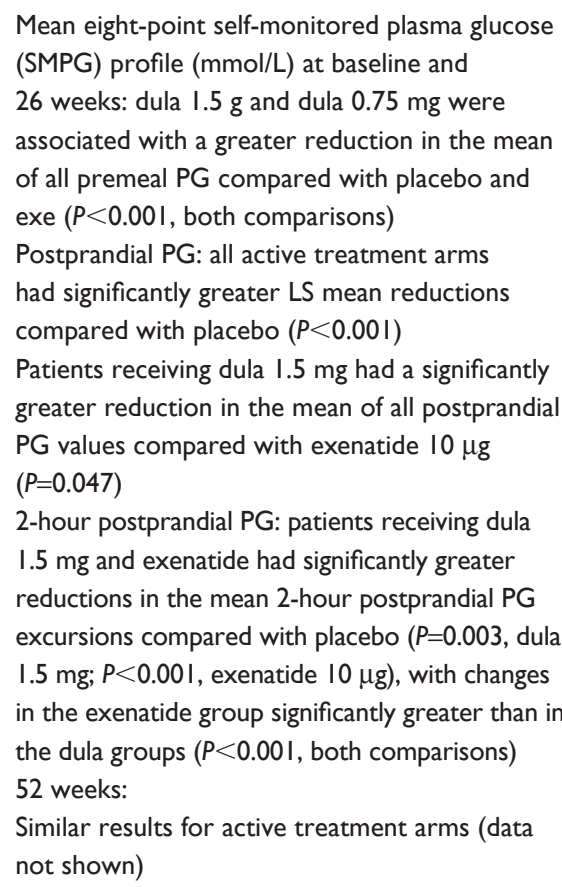 \\
\hline \multicolumn{4}{|c|}{ Dula I.5/0.75 mg/glargine } \\
\hline $\begin{array}{l}\text { Giorgino et } \mathrm{al}^{21} \\
\text { AWARD-2 (abs }\end{array}$ & $\mathrm{N} / \mathrm{A}$ & N/A & N/A \\
\hline \multicolumn{4}{|c|}{ Dula I.5/0.75 mg/sita/placebo } \\
\hline $\begin{array}{l}\text { Nauck et } \mathrm{al}^{22} \\
\text { AWARD-5 }\end{array}$ & $\begin{array}{l}\text { There was significant reduction in } \\
\text { FPG in the first } 2 \text { weeks with both } \\
\text { dulaglutide doses and with sitagliptin } \\
100 \mathrm{mg} \text { and the FPG levels remained } \\
\text { stable thereafter, whereas those in the } \\
\text { placebo arm showed small and slower } \\
\text { reduction in FPG overtime. } \\
52 \text { weeks: } \\
\text { Dula } 1.5:-26 \mathrm{mg} / \mathrm{dL} \text { (mean difference) } \\
\text { Dula } 0.75:-13 \mathrm{mg} / \mathrm{dL} \text { (mean difference) }\end{array}$ & $\begin{array}{l}52 \text { weeks: } \\
<0.00 \text { I, both } \\
\text { comparisons } \\
\text { with placebo. }\end{array}$ & NR \\
\hline Dula $1.5 \mathrm{mg} / \mathrm{l}$ & & & \\
\hline $\begin{array}{l}\text { Dungan et } \mathrm{al}^{20} \\
\text { (AWARD-6) }\end{array}$ & $\begin{array}{l}26 \text { weeks: } \\
\text { Dula: }-1.93, \text { SD } 2.07 \\
\text { Lira: }-1.9, \text { SD } 2.07\end{array}$ & $\begin{array}{l}\text { Reduction from baseline } \\
<0.000 \text { I (both groups) } \\
\text { Between groups: } 0.83\end{array}$ & $\begin{array}{l}26 \text { weeks: } \\
\text { Dula: }-2.56, \text { SD I.55 } \\
\text { Lira: }-2.43, \text { SD } 1.5\end{array}$ \\
\hline
\end{tabular}

Note: $* p<0.05$.

Abbreviations: AWARD, Assessment of Weekly Administration of Dulaglutide in Diabetes; Dula, dulaglutide; P, placebo; Exe, exenatide; Sita, sitagliptin; Lira, liraglutide; N/A, not available; SD, standard deviation; NR, not reported; FPG, fasting plasma glucose; FSG, fasting serum glucose; SMPG, self-monitored plasma glucose; DBP, diastolic blood pressure; SBP, systolic blood pressure; PPG, postprandial glucose; PG, plasma glucose; LS, least square.

\section{Insulin degludec}

There is a new generation, long-acting insulin analogue called "insulin degludec", trade name "Tresiba", marketed in the UK as basal insulin for people with type 2 diabetes. However, it has not been approved by FDA. Some trials have already been published. One trial compared insulin degludec against insulin glargine in patients previously treated with basal insulin. ${ }^{31}$ Another trial compared degludec against insulin glargine in people naïve to insulin therapy. ${ }^{32}$ Insulin degludec has also been compared against sitagliptin in patients naïve to insulin therapy. ${ }^{33}$ So far, no trials have been published comparing degludec with dulaglutide.

\section{On-going trials}

Searches for ongoing trials on https://clinicaltrials.gov showed a number of on-going studies. Some of the trials 


\begin{tabular}{llll}
\hline P-value & SBP (change from baseline) \\
$\mathrm{mmHg}$ & $P$-value & DBP (change from baseline) \\
& $\mathrm{mmHg}$ & $P$-value
\end{tabular}

26 weeks:

Dula I.5: 0.1 I, SD 13.8*

Dula $0.75:-0.36, S D 13.7^{*}$

Exe: $0.06, S D$ 13.7*

P: 3.4 , SD 13.4

52 weeks:

Dula I.5: 0.83 , SD 14.5

Dula $0.75:$ I.62, SD 14.2

Exe: 0.02 , SD 14.6
$* P<0.05$ vs placebo

26 weeks:

Dula I.5: 0.76, SD 9.I

Dula 0.75: 0.56, SD 0.0

Exe: -0.11 , SD 9.1

P: 1.25, SD 8.9

52 weeks:

Dula I.5: 0.89 , SD 9.5

Dula 0.75: 0.76, SD 0.02

Exe: 0.02 , SD 9.6

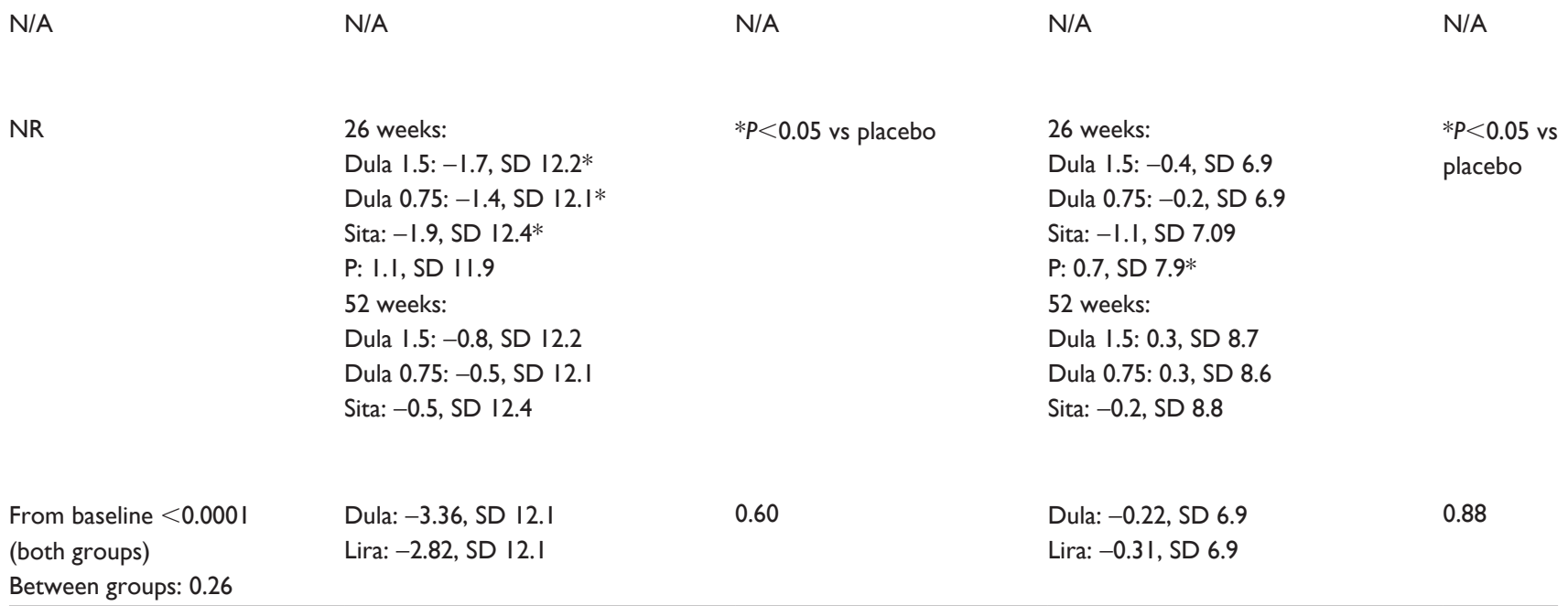

have been completed without results yet, while some trials are still recruiting. They include

- comparison of once-weekly dulaglutide with once-daily insulin glargine in patients with type 2 diabetes mellitus on metformin and/or an SU.

- comparison of dulaglutide to sitagliptin in patients with type 2 diabetes mellitus on metformin.

Results of one trial have been posted on the website clinicaltrials.gov (NCT01584232), but not yet published. It was again sponsored by Eli Lilly and company. It is a Phase III, randomized controlled trial conducted in Japan, comparing the efficacy of dulaglutide against insulin glargine in 361 patients with type 2 diabetes. The primary outcome was change in $\mathrm{HbA}_{1 \mathrm{c}}$ at 26 weeks.

Mean $\mathrm{HbA}_{1 \mathrm{c}}$ changes from baseline to primary endpoint are reported to show superiority of dulaglutide over insulin glargine (mean dose not reported) $(P<0.001)$. Greater percentages of patients in the dulaglutide arm 
Table 4 Adverse events, withdrawals, and hypoglycemia

\begin{tabular}{|c|c|c|c|c|c|}
\hline \multirow[t]{2}{*}{ Study } & \multirow{2}{*}{$\begin{array}{l}\text { Discontinuation } \\
\text { due to adverse } \\
\text { events, } n(\%)\end{array}$} & \multirow{2}{*}{$\begin{array}{l}\text { At least one } \\
\text { treatment-emergent } \\
\text { adverse event, } n(\%)\end{array}$} & \multicolumn{3}{|c|}{ Gastrointestinal events, n (\%) } \\
\hline & & & Nausea & Vomiting & Diarrhea \\
\hline \multicolumn{6}{|c|}{ Dula I.5/0.75/Exe/P } \\
\hline Wysham et $\mathrm{al}^{23}$ & 26 weeks: $8(3) /$ & 26 weeks: & 26 weeks: $78(28)^{* /}$ & 26 weeks: $47(17)^{* * * * /}$ & 26 weeks: $3 \mathrm{I}(\mathrm{II})$ \\
\hline \multirow[t]{4}{*}{ AWARD-I } & $4(1) / 9(3) / 3(2)$ & $215(77) / 199(71) /$ & $45(16)^{* * * * * * / 7 \mid}(26)^{*} /$ & $17(6) * * * * * / 30(1 \mathrm{I})^{* /}$ & $22(8) / 16(6) / 8(6)$ \\
\hline & 52 weeks: $9(3) /$ & $198(72) / 104(74)$ & 8 (6) 52 weeks: & 2 (I) 52 weeks: & 52 weeks: $36(13)$ \\
\hline & $4(1) / 10(4)$ & 52 weeks: $226(8 I) /$ & $81(29) / 47(17)^{* * / 77}(28)$ & $47(17) / 17(6)^{* * /} /$ & $26(9) / 21(8)$ \\
\hline & & $220(79) / 221(80)$ & & $33(12)$ & \\
\hline
\end{tabular}

Dula I.5/0.75 mg/glargine

Giorgino et $\mathrm{al}^{21} \quad$ NR

AWARD-2

\section{Dula I.5/0.75/sita/P}

$\begin{array}{lll}\text { Nauck et al }^{22} & 26 \text { weeks: } 2 \text { I (7)/ } & 26 \text { weeks: } 208(68)^{* * * * *} \text { I } \\ \text { AWARD-5 } & \text { I2(4)/I4 (4)/ } & 204(68)^{* * * * / I 85(59) /} \\ & 24(14) & \text { III (63) } \\ & 52 \text { weeks: } & 52 \text { weeks: } 233(77) / \\ & 33(11) / 23(8) / & 231(77) / 219(70) \\ & 30(10) & \end{array}$

26 weeks: $5 \mathrm{I}(17)^{\# * *} \mid$ $38(13)^{\#, * * * / 14}(4) / 7$ (4) 52 weeks: $53(17)^{\# I}$ $42(14)^{\# / / 6 ~(5) ~}$
$42(15.4) /$

$21(7.7) / 4(1.5)$
NR

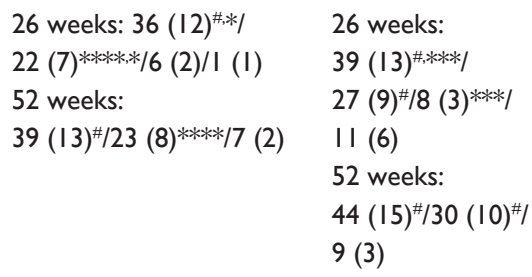

$29(10.6) / 25(9.2) /$

$15(5.7)$

Dula $1.5 \mathrm{mg} / \mathrm{lira}$

\begin{tabular}{|c|c|c|c|c|c|}
\hline Dungan et $\mathrm{al}^{20}$ & $18(6) / 18(6)$ & $185(62) / 189 / 63$ & $61(20) / 54(18)$ & $21(7) / 25(8)$ & $36(12) / 36(I 2)$ \\
\hline AWARD-6 & $P=0.99$ & $P=0.78$ & $P=0.46$ & $P=0.55$ & $P=0.995$ \\
\hline
\end{tabular}

Notes: ${ }^{P}<0.00$ I versus sitagliptin; $* P<0.00$ I versus placebo; $* * P<0.05$ versus exenatide $10 ; * * * P<0.05$ versus placebo; $* * * * P<0.05$ versus sitagliptin

Abbreviations: AWARD, Assessment of Weekly Administration of Dulaglutide in Diabetes; Dula, dulaglutide; P, placebo; Exe, exenatide; Sita, sitagliptin; Lira, liraglutide; SD, standard deviation; NR, not reported; TE, treatment-emergent; SE, standard error of the mean.

reached $\mathrm{HbA}_{1 \mathrm{c}}$ targets ( $\leq 6.5 \%: 51 \% ;<7 \%$ : 71\%) than in the glargine arm ( $\leq 6.5 \%: 24 \% ;<7 \%: 46 \%)$. Weight decreased with dulaglutide but increased with glargine $(P<0.005)$. The incidence of hypoglycemia was lower in patients with dulaglutide (26\%) than those on glargine (48\%). The most common gastrointestinal adverse events reported by patients treated with dulaglutide were nausea, vomiting, and diarrhea. 


\begin{tabular}{|c|c|c|c|c|c|c|}
\hline $\begin{array}{l}\text { Other gastrointestinal } \\
\text { events }\end{array}$ & $\begin{array}{l}\text { Serious adverse } \\
\text { events, } n(\%)\end{array}$ & $\begin{array}{l}\text { Pancreatitis, } \\
\text { n (\%) }\end{array}$ & $\begin{array}{l}\text { Positive } \\
\text { immunogenicity }\end{array}$ & $\begin{array}{l}\text { Deaths, } \\
\text { n (\%) }\end{array}$ & $\begin{array}{l}\text { Mild/moderate/ } \\
\text { overall hypos, } \mathbf{n}(\%)\end{array}$ & $\begin{array}{l}\text { Severe } \\
\text { hypos, n (\%) }\end{array}$ \\
\hline $\begin{array}{l}26 \text { weeks: } \\
\text { Dyspepsia: } 22(8) * * * / \\
5(2) * * / 19(7) 4(3) \\
\text { Constipation: I } 2(4) / \\
5(2) / 5(2) / 2(1) \\
\text { Flatulence: } 14(5) / 3(1) / \\
6 \text { (2)/3 (2) } \\
52 \text { weeks: } \\
\text { Dyspepsia: } 23(8) / \\
6(2)^{* * / 20 ~(7)} \\
\text { Constipation: } 16(6) / \\
5(2) / 5(2) \\
\text { Flatulence: } 16(6) / \\
3(1) / 7(3)\end{array}$ & $\begin{array}{l}26 \text { weeks: } 12(4) / \\
\text { I5 (5)/I5 (5) I2 (9) } \\
52 \text { weeks: } 18(7) / \\
22(8) / 27(10)\end{array}$ & NR & $\begin{array}{l}\text { Anti-drug antibodies } \\
26 \text { weeks (I.5/0.75/ } \\
\text { exe/P): antibodies: } \\
4(1.4) / 2(0.7) / \\
\text { I2 (4.3) } 2(1.4) \\
52 \text { weeks: }(1.5 / \\
0.75 / \text { exe): } 5(1.8) / \\
3(1.1) / 14(5.1)\end{array}$ & $\begin{array}{l}26 \text { weeks: } \\
\text { I }(0.4) / I(0.4) / \\
0(0) / 0(0) \\
52 \text { weeks: } \\
\text { I }(0.4) / /(0.4) / \\
0(0)\end{array}$ & $\begin{array}{l}26 \text { weeks: dula I.5/0.75/ } \\
\text { exe/P: } 29(10.4) / 30 \\
(I 0.7) / 44(15.9) / \\
50(3.5) \\
\text { Mean I year } \\
\text { adjusted rates of } \\
\text { total hypoglycemia } \\
0.45 / I .10 / 1.47 / 0.37 \\
\text { events/patient/year } \\
52 \text { weeks: rates and } \\
\text { incidence of total } \\
\text { hypoglycemia } \\
\text { remained lower for } \\
\text { dulaglutide I.5 mg } \\
\text { compared to } \\
\text { exenatide } 10 \mu \mathrm{g}\end{array}$ & $\begin{array}{l}\text { Exe: } 2 \\
\text { None in } \\
\text { dulaglutide } \\
\text { groups }\end{array}$ \\
\hline NR & NR & NR & NR & NR & $\begin{array}{l}78 \text { weeks symptomatic } \\
\text { hypoglycemia } \\
\text { ( } \leq 70 \mathrm{mg} / \mathrm{dL} \text { ) event/ } \\
\text { patient/year) } 1.7 / / / 7 / 3 \\
\text { ( } P \leq 0.002 \text { both) }\end{array}$ & $\begin{array}{l}\text { Severe } \\
\text { hypoglycemia } \\
\text { was minimal } \\
\text { with dula and } \\
\text { glargine }\end{array}$ \\
\hline $\begin{array}{l}26 \text { weeks: } \\
\text { Abdominal pain: I3 (4)/ } \\
\text { II (4)6 (2)/3 (2) } \\
\text { Dyspepsia: I3 (4)/ } \\
\text { I4 (5)/8 (3)/2 (I) } \\
\text { Abdominal distension: } \\
\text { I2 (4)//2 (4)/3 (I)/I (I) } \\
52 \text { weeks: } \\
\text { Abdominal pain: I8 (6)/ } \\
\text { I2 (4)//0 (3) } \\
\text { Dyspepsia: I4 (5)/ } \\
\text { I8 (6)/9 (3) } \\
\text { Abdominal distension: } \\
\text { I2 (4)/I4 (5)/3 (I) }\end{array}$ & $\begin{array}{l}26 \text { weeks: } 17(6) / \\
10(3) / / I(4) / \\
6(3) \\
52 \text { weeks: } \\
26(9) / 16(5) / \\
17(5)\end{array}$ & $\begin{array}{l}\text { Acute } \\
\text { pancreatitis: } \\
\text { Dula/Sita/P: } \\
\text { 0/2/I }\end{array}$ & $\begin{array}{l}26 \text { weeks: dula } \\
\text { anti-drug antibodies } \\
(1.5 / 0.75 / \text { sita/P): } \\
2(<\mathrm{I}) / 6(2) / \mathrm{I} \\
(<\mathrm{I}) / 0(0) \\
52 \text { weeks: }(1.5 / 0.75 / \\
\text { sita): } 2(<\mathrm{I}) / 7(2) / \\
2(<\mathrm{I})\end{array}$ & $\begin{array}{l}26 \text { weeks: } \\
\text { I }(<\mathrm{I}) / 0(0) / \\
0(0) / 0(0) \\
52 \text { weeks: I }(<\mathrm{I}) / \\
0(0) / 2(<\mathrm{I})\end{array}$ & $\begin{array}{l}26 \text { weeks: NR } \\
52 \text { weeks: } \\
\text { Mean (SD) I year } \\
\text { adjusted rates } \\
\text { (events/patient/year) } \\
\text { Dula I.5: } 0.4 \text {, SD I.6 } \\
\text { Dula 0.75: 0.3, } \\
\text { SD 2.6 } \\
\text { Sita: } 0.1 \text {, } \\
\text { SD I.I }\end{array}$ & $\begin{array}{l}\text { There were } \\
\text { no severe } \\
\text { hypoglycemic } \\
\text { events } \\
\text { reported }\end{array}$ \\
\hline $\begin{array}{l}\text { Dyspepsia: } 24 \text { (8)/ } \\
\text { I8 (6), } P=0.33 \\
\text { Constipation: II (4)/ } \\
\text { I7 (6), } P=0.25\end{array}$ & $\begin{array}{l}5(2) / 11(4) \\
P=0.13\end{array}$ & $\begin{array}{l}\text { No cases of } \\
\text { pancreatic } \\
\text { cancer or } \\
\text { adjudicated } \\
\text { pancreatitis }\end{array}$ & $\begin{array}{l}3 \text { (I\%) patient } \\
\text { developed TE antibodies } \\
\text { to dulaglutide. Liraglutide } \\
\text { group was not assessed. } \\
\text { None of these patient } \\
\text { developed } \\
\text { hypersensitivity } \\
\text { reactions }\end{array}$ & 0 & $\begin{array}{l}\text { Dula/lira: } 26(9) / \\
17(6) \\
\text { Overall rate } \\
\text { (events/patient/year): } \\
\text { Mean event rate } \\
\text { of } 0.34 \text { (SE I.44) } \\
\text { events/patient /year } \\
\text { for dula compared } \\
\text { with } 0.52(3.0 \mathrm{I}) \text { for lira }\end{array}$ & $\begin{array}{l}\text { None in all } \\
\text { groups }\end{array}$ \\
\hline
\end{tabular}

\section{Pancreatitis / pancreatic cancer and thyroid cancer risks}

Concern has been raised about the risk of acute pancreatitis and pancreatic tumors with GLP-1 receptor agonists, ${ }^{34}$ and the FDA noted the pancreatitis risk in connection with longacting exenatide. However, since then several studies have found no increased risk of pancreatitis. Li et al ${ }^{35}$ carried out a good quality systematic review of 55 randomized trials and 5 
observational studies and concluded that the GLP-1 receptor agonists drugs did not increase the risk of pancreatitis.

Faillie et $\mathrm{al}^{36}$ used data from the UK Clinical Practice Research Database on 20,748 users on incretin drugs (liraglutide, exenatide, and four DPP-4 inhibitors) and found no increase in pancreatitis compared to people with type 2 diabetes on SU, but did not report results separately for the GLP-1 receptor agonists. Montori ${ }^{37}$ concluded that the evidence to date suggests that the incretin drugs do not increase the incidence of pancreatitis.

Both the FDA ${ }^{38}$ and the $\mathrm{EMA}^{14}$ state that the safety profile of dulaglutide is similar to the safety profile of other GLP-1 receptor agonists. They add that there may be a risk of pancreatic and thyroid cancer, but there are no long-term data available. Therefore, EMA has requested the manufacturer to submit periodic safety update reports. ${ }^{14}$ FDA has also made recommendations for postmarketing risk evaluation and mitigation strategies to assess the risk of thyroid C-cell tumor and pancreatitis. ${ }^{38}$ The FDA has also asked the manufacturer to undertake the following: a study in a pediatric population, a toxicity study in immature rats, setting up of a MTC case registry of at least 15 years duration to record cases of MTC related to dulaglutide, a study comparing dulaglutide and insulin glargine in patients with moderate to severe renal impairment, and a study on cardiovascular outcomes. ${ }^{38}$

\section{Research needs}

As with all new drug entities, long-term surveillance will be required to detect rare adverse events. The FDA issued a warning for long-acting exenatide about the need for monitoring for thyroid cancer, while noting that the evidence for an increase in risk comes from rats and that there is no evidence that a similar effect could occur in humans. ${ }^{38}$

Robinson et $\mathrm{al}^{39}$ noted a slight increase in heart rate by about 2 beats per minute with GLP-1 receptor agonists, more evident for liraglutide and long-acting exenatide than twice-daily exenatide, but of uncertain clinical significance. A review of trial data on five long-acting GLP-1 1 receptor agonists (exenatide, taspoglutide, albiglutide, LY2189265, and CJC-1134-PC) concluded that they were more likely to raise heart rate than short-acting GLP-1 receptor agonists. ${ }^{40}$

A study of the long-acting GLP-1 agonist PF-04603629 reported a rise of 23 beats per minute in heart rate at 24 hours after injection of the higher dose together with a rise in diastolic pressure. ${ }^{41}$

Ferdinand et $\mathrm{al}^{42}$ investigated the effect of dulaglutide on blood pressure and heart rate in patients with type 2 diabetes and found that it led to reduction in 24-hour SBP (1.5 mg vs placebo: $-2.8 \mathrm{mmHg}, 95 \% \mathrm{CI}$ : -4.6 to -1.0 ) and an increment in 24-hour heart rate (dulaglutide $0.75 \mathrm{mg}$ vs placebo: $1.6 \mathrm{bpm}, 95 \% \mathrm{CI}$ : 0.3-2.9; $1.75 \mathrm{mg}$ vs placebo: $2.8 \mathrm{bpm}$, $95 \%$ CI: $1.5-4.2$ ). The evidence to date on dulaglutide is only in people with type 2 diabetes, but there is a little evidence that this group of drugs may be of benefit in type 1 diabetes too, and further research is needed there. Once-weekly exenatide has been tried in type 1 diabetes mellitus in combination with continuous subcutaneous insulin infusion therapy. ${ }^{43}$

\section{Conclusion}

The review finds that dulaglutide is effective in the treatment of patients with type 2 diabetes mellitus, and may have advantages, such as in weight change, over some active comparators. Dulaglutide was found to be noninferior to liraglutide $1.8 \mathrm{mg}$. The incidence of hypoglycemia was found to be lower with dulaglutide. Longer term follow-up data are needed for reassurance on safety.

\section{Disclosure}

DSS is currently employed by Eli Lilly. However, while undertaking this review he was only employed by the University of Warwick. The authors report no other conflicts in interest in this work.

\section{References}

1. Turner R, Cull C, Holman R. United Kingdom prospective diabetes study 17: a 9-year update of a randomized, controlled trial on the effect of improved metabolic control on complications in non-insulin-dependent diabetes mellitus. Ann Intern Med. 1996;124(1 Pt 2):136-145.

2. Internation diabetes federation (IDF). Diabetes Atlas. 6th ed. Brussels, Belgium: IDF; 2013. Available from: http://www.idf.org/diabetesatlas. Accessed December 1, 2014

3. Nathan DM, Buse JB, Davidson MB, et al. Medical management of hyperglycemia in type 2 diabetes: a consensus algorithm for the initiation and adjustment of therapy: a consensus statement of the American Diabetes Association and the European Association for the Study of Diabetes. Diabetes Care. 2009;32(1):193-203.

4. Inzucchi SE, Bergenstal RM, Buse JB, et al. Management of hyperglycemia in type 2 diabetes, 2015: a patient-centered approach: update to a position statement of the American Diabetes Association and the European Association for the Study of Diabetes. Diabetes Care. 2015;38(1):140-149

5. Baggio LL, Huang Q, Brown TJ, Drucker DJ. A recombinant human glucagon-like peptide (GLP)-1-albumin protein (albugon) mimics peptidergic activation of GLP-1 receptor-dependent pathways coupled with satiety, gastrointestinal motility, and glucose homeostasis. Diabetes. 2004;53(9):2492-2500.

6. Nauck MA, Kleine N, Orskov C, Holst JJ, Willms B, Creutzfeldt W. Normalization of fasting hyperglycemia by exogenous glucagon-like peptide 1 (7-36 amide) in type 2 (non-insulin-dependent) diabetic patients. Diabetologia. 1993;36(8):741-744.

7. Amori RE, Lau J, Pittas AG. Efficacy and safety of incretin therapy in type 2 diabetes: systematic review and meta-analysis. JAMA. 2007;298(2):194-206.

8. Barnett AH. New treatments in type 2 diabetes: a focus on the incretinbased therapies. Clin Endocrinol. 2009;70(3):343-353.

9. Monami M, Marchionni N, Mannucci E. Glucagon-like peptide-1 receptor agonists in type 2 diabetes: a meta-analysis of randomized clinical trials. Eur J Endocrinol. 2009;160(6):909-917. 
10. Norris SL, Lee N, Thakurta S, Chan BK. Exenatide efficacy and safety: a systematic review. Diabet Med. 2009;26(9):837-846.

11. Shyangdan DS, Royle PL, Clar C, Sharma P, Waugh NR. Glucagonlike peptide analogs for type 2 diabetes mellitus: systematic review and meta-analysis. BMC Endocr Disord. 2010;10:20.

12. National Institute for Health and Care Excellence (NICE). Type 2 Diabetes: The Management of Type 2 Diabetes; NICE Clinical Guideline 87. London, UK: NICE; 2014. Available from: http://www. nice.org.uk/cg87. Accessed December 1, 2014.

13. European Medicines Agency (EMA). Trulicity. Summary of Product Characteristics. London, UK: EMA; 2014. Available from: http://www. ema.europa.eu/docs/en_GB/document_library/EPAR_-_Product_Information/human/002825/WC500179470.pdf. Accessed May 5, 2015.

14. European Medicines Agency (EMA). EPAR Trulicity. London, UK: EMA; 2014. Available from: http://www.ema.europa.eu/docs/en_GB/ document_library/EPAR_-_Public_assessment_report/human/002825/ WC500179473.pdf. Accessed January 5, 2015.

15. Eli Lilly. FDA Approves Trulicity (Dulaglutide), Lilly's Once Weekly Therapy for Adults with Type 2 Diabetes. Indianapolis, IN: Eli Lilly; 2014. Available from: https://investor.lilly.com/releasedetail. cfm?ReleaseID=871658. Accessed October 1, 2014.

16. Shyangdan DS, Royle P, Clar C, Sharma P, Waugh N, Snaith A. Glucagon-like peptide analogs for type 2 diabetes mellitus. Cochrane Database Syst Rev. 2011;(10):Cd006423.

17. National Institute for Health and Care Excellence (NICE). NICE CG66. Type 2 Diabetes (Partially Updated by CG87). London, UK: NICE; 2008. Available from: http://www.nice.org.uk/guidance/cg66. Accessed December 12, 2014

18. Scottish Intercollegiate Guidelines Network (SIGN). Management of Diabetes. A National Guideline. SIGN 116. Edinburgh, Scotland: SIGN; 2010. Available from: http://www.sign.ac.uk/pdf/sign116.pdf. Accessed December 10, 2014.

19. National Institute for Health and Care Excellence (NICE). Type 2 Diabetes in Adults: Management of Type 2 Diabetes in Adults. NICE Guideline Draft for Consultation, January 2015. London, UK, NICE; 2015. Available from: http://www.nice.org.uk/Guidance/InDevelopment/GID-CGWAVE0612. Accessed February 10, 2015.

20. Dungan KM, Povedano ST, Forst T, et al. Once-weekly dulaglutide versus once-daily liraglutide in metformin-treated patients with type 2 diabetes (AWARD-6): a randomized, openlabel, phase 3, non-inferiority trial. Lancet. 2014;384(9951): 1349-1357.

21. Giorgino F, Benroubi M, Sun JH, Zimmermann AG, Pechtner V. Efficacy and safety of once-weekly dulaglutide vs insulin glargine in combination with metformin and glimepiride in type 2 diabetes patients (AWARD-2). Diabetes. 2014;63:A87.

22. Nauck M, Weinstock RS, Umpierrez GE, Guerci B, Skrivanek Z, Milicevic Z. Efficacy and safety of dulaglutide versus sitagliptin after 52 weeks in type 2 diabetes in a randomized controlled trial (AWARD-5). Diabetes Care. 2014;37(8):2149-2158.

23. Wysham C, Blevins T, Arakaki R, et al. Efficacy and safety of dulaglutide added onto pioglitazone and metformin versus exenatide in type 2 diabetes in a randomized controlled trial (AWARD-1). Diabetes Care. 2014;37(8):2159-2167.

24. Jendle J, Rosenstock J, Blonde L, et al. Better glycemic control and less weight gain with once-weekly dulaglutide vs. once-daily insulin glargine, both combined with premeal insulin lispro, in type 2 diabetes patients (AWARD-4). Diabetes. 2014;63: A246-A247.

25. Eli Lilly. A study in participants with type 2 diabetes mellitus (AWARD-2). Available from: https://clinicaltrials.gov/ct2/show/ NCT01075282?term $=$ NCT01075282\&rank=1. NLM identifier: NCT01075282. Accessed May 30, 2015.

26. Umpierrez G, Povedano ST, Manghi FP, Shurzinske L, Pechtner V. Efficacy and safety of dulaglutide monotherapy versus metformin in type 2 diabetes in a randomized controlled trial (AWARD-3). Diabetes Care. 2014;37(8):2168-2176.
27. Grunberger G, Chang A, Garcia Soria G, Botros FT, Bsharat R, Milicevic Z. Monotherapy with the once-weekly GLP-1 analog dulaglutide for 12 weeks in patients with Type 2 diabetes: dose-dependent effects on glycemic control in a randomized, double-blind, placebo-controlled study. Diabet Med. 2012;29(10):1260-1267.

28. Terauchi Y, Satoi Y, Takeuchi M, Imaoka T. Monotherapy with the once weekly GLP-1 receptor agonist dulaglutide for 12 weeks in Japanese patients with type 2 diabetes: dose-dependent effects on glycemic control in a randomized, double-blind, placebo-controlled study. Endocr $J$. 2014;61(10):949-959.

29. Waugh N, Cummins E, Royle P, et al. Newer agents for blood glucose control in type 2 diabetes: systematic review and economic evaluation. Health Technol Assess. 2010;14(36):1-248.

30. Richter B, Bandeira-Echtler E, Bergerhoff K, Lerch CL. Dipeptidyl peptidase-4 (DPP-4) inhibitors for type 2 diabetes mellitus. Cochrane Database Syst Rev. 2008;(2):Cd006739.

31. Garber AJ, King AB, Del Prato S, et al. Insulin degludec, an ultralongacting basal insulin, versus insulin glargine in basal-bolus treatment with mealtime insulin aspart in type 2 diabetes (BEGIN Basal-Bolus Type 2): a phase 3, randomized, open-label, treat-to-target non-inferiority trial. Lancet. 2012;379(9825):1498-1507.

32. Zinman B, Philis-Tsimikas A, Cariou B, et al. Insulin degludec versus insulin glargine in insulin-naive patients with type 2 diabetes: a 1-year, randomized, treat-to-target trial (BEGIN Once Long). Diabetes Care. 2012;35(12):2464-2471.

33. Philis-Tsimikas A, Del Prato S, Satman I, et al. Effect of insulin degludec versus sitagliptin in patients with type 2 diabetes uncontrolled on oral antidiabetic agents. Diabetes Obes Metab. 2013;15(8):760-766.

34. Gale E. Incretin therapy: should adverse consequences have been anticipated? BMJ. 2013;346:f3617.

35. Li L, Shen J, Bala MM, et al. Incretin treatment and risk of pancreatitis in patients with type 2 diabetes mellitus: systematic review and meta-analysis of randomized and non-randomized studies. BMJ. 2014;348:g2366.

36. Faillie JL, Azoulay L, Patenaude V, Hillaire-Buys D, Suissa S. Incretin based drugs and risk of acute pancreatitis in patients with type 2 diabetes: cohort study. BMJ. 2014;348:g2780.

37. Montori VM. The safety of incretin based drugs. BMJ. 2014;348: g2779.

38. Food and Drug Administration (FDA). Summary Review. Dulaglutide. Silver Spring, MD: FDA; 2014. Available from: http://www.accessdata. fda.gov/drugsatfda_docs/nda/2014/125469Orig1s000SumR.pdf. Accessed January 5, 2015

39. Robinson LE, Holt TA, Rees K, Randeva HS, O'Hare JP. Effects of exenatide and liraglutide on heart rate, blood pressure and body weight: systematic review and meta-analysis. BMJ Open. 2013;3(1).

40. Madsbad S, Kielgast U, Asmar M, Deacon CF, Torekov SS, Holst JJ. An overview of once-weekly glucagon-like peptide-1 receptor agonists - available efficacy and safety data and perspectives for the future. Diabetes Obes Metab. 2011;13(5):394-407.

41. Gustavson SM, Chen D, Somayaji V, et al. Effects of a long-acting GLP-1 mimetic (PF-04603629) on pulse rate and diastolic blood pressure in patients with type 2 diabetes mellitus. Diabetes Obes Metab. 2011;13(11):1056-1058.

42. Ferdinand KC, White WB, Calhoun DA, et al. Effects of the once-weekly glucagon-like peptide-1 receptor agonist dulaglutide on ambulatory blood pressure and heart rate in patients with type 2 diabetes mellitus. Hypertension. 2014;64(4):731-737.

43. Traina AN, Lull ME, Hui AC, Zahorian TM, Lyons-Patterson J. Onceweekly exenatide as adjunct treatment of type 1 diabetes mellitus in patients receiving continuous subcutaneous insulin infusion therapy. Can J Diabetes. 2014;38(4):269-272.

44. Bain SC, Skrivanek Z, Tahbaz A, Pechtner V, Adetunji O. Efficacy of long-acting once weekly dulaglutide compared with short-acting twice daily (bid) exenatide in patients with Type 2 diabetes: A posthoc analysis to determine the influence of baseline $\mathrm{HbAlc}$ in the Assessment of Weekly Administration of LY2189265 in Diabetes-1 (AWARD-1) trial. Diabetic Medicine. 2014;31:50 


\section{Supplementary material}

Table SI Search strategy: MEDLINE

I. Exp glucagon-like peptides/

2. (Glucagon like peptide* or GLP-I).tw.

3. (Dulaglutide or LY2I89265 or GLP-I Fc).tw.

4. 1 or 2 or 3

5. (Random* or blind* or placebo or trial).tw.

6. Randomized controlled trial.pt.

7. Random\$.tw.

8. 5 or 6 or 7

9. Diabetes mellitus, type $2 /$

10. Type 2 diabetes mellitus.tw.

II. 9 or 10

12. 4 and 8 and II

13. Limit 12 to (English language and humans and year = "2005current")

Note: The above search strategy was adopted for other databases.

\section{Publish your work in this journal}

Diabetes, Metabolic Syndrome and Obesity: Targets and Therapy is an international, peer-reviewed open-access journal committed to the rapid publication of the latest laboratory and clinical findings in the fields of diabetes, metabolic syndrome and obesity research. Original research, review, case reports, hypothesis formation, expert opinion and commentaries are all considered for publication. The manuscript management system is completely online and includes a very quick and fair peer-review system, which is all easy to use. Visit http://www.dovepress.com/testimonials.php to read real quotes from published authors.

Submit your manuscript here: http://www.dovepress.com/diabetes-metabolic-syndrome-and-obesity-targets-and-therapy-journal 